\title{
10. EVIDENCE FOR CONTINUOUS AND DISCONTINUOUS ALTERATION IN DSDP HOLE 418A BASALTS AND ITS SIGNIFICANCE TO NATURAL GAMMA-RAY LOG READINGS ${ }^{1}$
}

\author{
M. A. Holmes, University of Nebraska-Lincoln, Lincoln, Nebraska²
}

\begin{abstract}
During Ocean Drilling Program Leg 102, the Schlumberger natural gamma-ray spectrometry tool measured high potassium levels in one interval of DSDP Hole 418A basalts. Samples from that hole were examined by X-ray diffraction, SEM, and EDS analyses in order to identify mineral species responsible for the high readings. The results indicate that high $\mathrm{K}$ readings observed on wireline logs run in basement can be attributed to extensive low-temperature oxidative alteration resulting in formation of palagonite and K-rich clays (celadonite, potassic nontronite, and mixed-layer celadonite/nontronite). Where these readings are accompanied by high porosity, low density, and low velocity readings, a breccia with a once-glassy matrix, now altered to K-rich clay, may be inferred. Where porosity, density, and velocity readings indicate no breccia, high $\mathrm{K}$ readings may be attributed to potassium feldspar, an indicator of a second stage of oxidative alteration. In either case, there is a significant contribution to the $\mathrm{K}$ readings from palagonite.

Further results of this study indicate a continuous fluid evolution and secondary mineral formation in these basalts. An initial stage of oxidation and formation of iron oxide-hydroxides was followed by precipitation of K-rich clay minerals. The first clays to form may have been celadonite, mixed-layer celadonite/nontronite, or potassic nontronite. As the fluid evolved, the minerals formed were increasingly depleted in $\mathrm{K}$ and ferric iron and increasingly enriched in $\mathrm{Mg}, \mathrm{Al}$, $\mathrm{Ca}$, and ferrous iron. The final phase was an iron-rich saponite. In at least one interval with high permeability, a second stage of oxidative alteration resulting from the influx of a new fluid is demonstrated by the alteration of saponite to iddingsite (saponite + goethite). Potassium feldspar is associated with this zone and is believed to have formed with the second stage of oxidative alteration.
\end{abstract}

\section{INTRODUCTION}

During Ocean Drilling Program (ODP) Leg 102, the Schlumberger natural gamma-ray spectrometry tool (NGT) was run through open hole between 464 and $789 \mathrm{~m}$ below seafloor (mbsf) as part of the conventional logging of Deep Dea Drilling Project (DSDP) Hole 418A. The NGT is designed to detect potassium levels between $0 \%$ and $10 \%$, thorium up to $40 \mathrm{ppm}$, and uranium up to $30 \mathrm{ppm}$. High levels of potassium (K), from $0.3 \%$ to $1.5 \%$, were detected from 460 to $515 \mathrm{mbsf}$ (DSDP Cores $418 \mathrm{~A}-35$ to $418 \mathrm{~A}-42$ ). Even the minimum reading represents a $400 \%$ increase in $\mathrm{K}$ levels for these basalts. Potassium and water are the first components taken up by basalts during low-temperature submarine alteration, and levels increase with increasing degree of alteration (e.g., Hart, 1969; Seidemann, 1977; Staudigel et al., 1980b). This is predominantly a low-temperature phenomenon (Muehlenbachs, 1980; Lawrence, 1980). In Hole 418A, several K-rich phases formed as a result of submarine alteration, including palagonite, $\mathrm{K}$-rich clay, potassium feldspar, and several zeolites (Pritchard, 1980; Humphris et al., 1980; Pertsev and Rusinov, 1980). The current study was undertaken to correlate high $\mathrm{K}$ readings by the Schlumberger NGT with K-bearing phases in Hole 418A basalts using X-ray diffractometry (XRD) and scanning electron microscopy (SEM) in conjunction with an energy-dispersive X-ray spectrometer (EDS). This correlation could aid in interpretation of future NGT readings in basalts.

\section{BASALTS OF DSDP HOLE 418A}

\section{General Description}

An 868-m section, of which $544 \mathrm{~m}$ was in basement, was cored at DSDP Hole 418A during Legs 52 and 53 in early 1977.

\footnotetext{
${ }^{1}$ Salisbury, M. H., Scott, J. H., et al., Proc. ODP, Sci. Results, 102: College Station, TX, (Ocean Drilling Program).

2 Address: Department of Geology, University of Nebraska-Lincoln, Lincoln, NE 68588-0340.
}

The site is located on the $M 0$ anomaly, on the southern flank of the Bermuda Rise (Fig. 1), only a few kilometers from DSDP Holes 417A and 417D. Before Hole 418A could be conventionally logged, the sonic velocity tool apparently became stuck in the hole. The cable was then severed and the reentry hole abandoned (Shipboard Scientific Parties, 1980). The opportunity to return to the hole and log it did not recur until ODP Leg 102 in early 1985 .

The $544 \mathrm{~m}$ of basalt drilled during DSDP Legs 52 and 53 were divided into 16 lithologic units (Fig. 2 and Table 1) based on cooling characteristics and phenocryst content (Shipboard Scientific Parties, 1980). Detailed descriptions of these units are published in DSDP Volumes 51, 52, and 53 (Donnelly, Francheteau, et al., 1980), and only a brief summary is given in Table 1 and Figure 2. The recovered rocks consist of pillow basalt and breccia (Units 5,13 , and 16), pillow basalts (Units/Subunits 1, 3, 6B, 7, 8A, $8 \mathrm{C}$, and 11 ), breccia (Subunit 6A), massive basalts (Units/Subunits 2, 4, 8B, 9, 10, 12, and 14), and basalt dikes (Unit 15). The basalts are sparsely to moderately phyric. Phenocryst assemblages are dominated by plagioclase and include olivine and clinopyroxene, with minor spinel (Subunits 6A and 6B only). Plagioclase phenocrysts make up $2 \%$ to $10 \%$ of the rock and olivine phenocrysts usually make up $1 \%$ to $3 \%$. The basement lithologic units that were logged through open hole during ODP Leg 102 include the lower part of lithologic Unit 5 through the upper part of lithologic Subunit 14B (Fig. 2). Basement lithologic Unit 5 and Subunit $6 \mathrm{~A}$ gave high $\mathrm{K}$ readings on the NGT $\log$ (Fig. 2).

The basalts of Hole 418A are moderately altered throughout, although fresh glass and unaltered clinopyroxene phenocrysts can be found throughout the core. Humphris et al. (1980) estimated that alteration products do not exceed $20 \%$ of the recovered basalt. Smectite, calcite, and quartz are the most common secondary minerals, typically filling veins and vesicles or replacing glass (Shipboard Scientific Parties, 1980). Much of the glass is altered to clay, and almost all of the olivine is replaced by clay (Pl. 1, Fig. 1) or by calcite. Many of the plagioclase phenocrysts are partly replaced by calcite (Pl. 1, Fig. 2) 


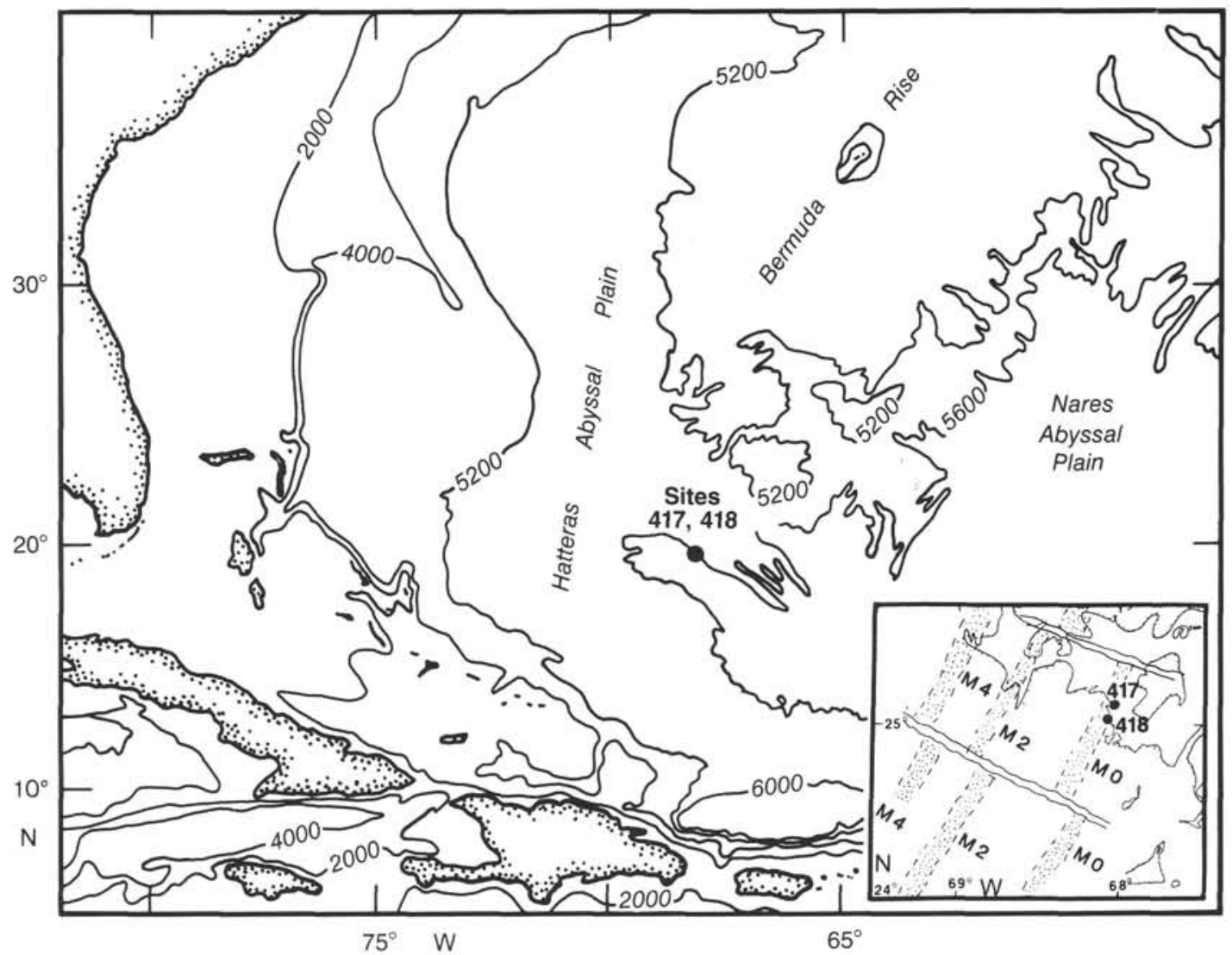

Figure 1. Location of DSDP Sites 417 and 418 . Bathymetry in meters.

and are altered to clays and/or potassium feldspars along cleavage planes and at outer rims (Pl. 1, Fig. 3). Veins and vesicles are filled with carbonate, clay, or a combination of these (PI. 1, Figs. 1 and 4 through 6) and may have zeolites present. Some secondary pyrite is observed in the groundmass, in veins (Shipboard Scientific Parties, 1980; Pertsev and Rusinov, 1980; Humphris et al., 1980), and as replacement of olivine (Humphris et al., 1980). Iron oxides have precipitated along many fractures (Pl. 1, Figs. 4 through 6). Alteration intensity in Hole 418A does not vary significantly with depth (Shipboard Scientific Parties, 1980), but two zones, lithologic Unit 5 and Subunit 6A, are more altered, as shown by the presence of potassium feldspar and abundant iron oxides-hydroxides (Humphris et al., 1980; Pertsev and Rusinov, 1980).

Oxygen-isotope analyses indicate that alteration occurred under low-temperature conditions. Scarfe (1980) reported $\delta^{8} \mathrm{O}$ values of $17.1 \% 0$ and $18.1 \%_{0}$ in two clay samples from Hole $418 \mathrm{~A}$, which are indicative of low temperatures of formation. Isotopic analyses of basalts, carbonates, and a clay by Muehlenbachs (1980) indicate that basalts are enriched in ${ }^{18} \mathrm{O}$ during alteration by cold seawater. Lawrence (1980) estimated temperatures of formation of carbonates in nearby Holes 417A and 417D of $14.6^{\circ}$ to $41.2^{\circ} \mathrm{C}$.

\section{Chemistry of Rocks and Minerals}

In general, fresh basalts from this hole have chemical analyses similar to basalts produced at the modern Mid-Atlantic Ridge (Byerly and Sinton, 1980), with the exception that potassium levels are low (Staudigel et al., 1980b). The average $\mathrm{K}_{2} \mathrm{O}$ level of 111 fresh-glass samples is $0.09 \%$, with $91 \%$ of the samples having less than $0.12 \%$ (Byerly and Sinton, 1980). Lithologic Unit 5 averages $0.08 \% \mathrm{~K}_{2} \mathrm{O}$ in fresh glasses; no fresh glasses were obtained from lithologic Subunit 6A. In addition, the levels of $\mathrm{K}_{2} \mathrm{O}$ in primary minerals from Hole $418 \mathrm{~A}$ are very low. The $\mathrm{K}_{2} \mathrm{O}$ levels in glassy inclusions in clinopyroxene phenocrysts range from $0.01 \%$ to $0.11 \%$, whereas the host clinopyroxene has $\mathrm{K}_{2} \mathrm{O}$ levels of less than $0.02 \%$ (Clocchiatti, 1980). Staudigel et al. (1980a) and Humphris et al. (1980) detected no $\mathrm{K}_{2} \mathrm{O}$ in olivine or clinopyroxene from Hole $418 \mathrm{~A}$. Plagioclase phenocrysts have $\mathrm{K}_{2} \mathrm{O}$ contents ranging from $0.01 \%$ to $0.12 \%$ (Bollinger and Semet, 1980).

Alteration of basalts is marked by an increase in $\mathrm{K}_{2} \mathrm{O}$ levels, as illustrated by measurements from whole-rock samples compared to those from fresh glass and unaltered phenocrysts. The average $\mathrm{K}_{2} \mathrm{O}$ level measured on 152 whole-rock samples from Hole $418 \mathrm{~A}$ was $0.156 \%$ (Flower et al., 1980), which is significantly higher (by F-test, $\mathrm{C}>99.9 \%$ ) than that measured for fresh glass by Byerly and Sinton (1980). Levels of $\mathrm{K}_{2} \mathrm{O}$ in wholerock samples (by laboratory analysis; Flower et al., 1980) vary from $0.02 \%$ to $2.28 \%$ depending on the degree of alteration in each lithologic unit (Fig. 3). The highest levels were measured in lithologic Subunit $6 \mathrm{~A}$ (average, $0.62 \%$ ), followed by the pillow basalts and breccias of lithologic Unit 5 (average, $0.44 \%$; maximum, $2.28 \%$ ). Staudigel et al. (1980a) analyzed 24 glass/wholerock pairs from Hole $418 \mathrm{~A}$ and noted a systematic increase in $\mathrm{K}, \mathrm{H}_{2} \mathrm{O}$, and $\mathrm{Fe}_{2} \mathrm{O}_{3} / \mathrm{FeO}$ levels in whole rock compared to glasses.

Secondary minerals that have high $\mathrm{K}$ levels include a K-rich clay mineral (termed "proto-celadonite" on Legs 51, 52, and 53), potassium feldspar, and the zeolites phillipsite and apophyllite (Pertsev and Rusinov, 1980). Palagonite, also with an elevated $\mathrm{K}$ level, appears to be a microcrystalline smectite (Juteau et al., 1980). Rusinov et al. (1980) and Juteau et al. (1980) reported $\mathrm{K}_{2} \mathrm{O}$ levels in palagonite samples from Holes 417A and $417 \mathrm{D}$ that ranged from $0.04 \%$ to $4.08 \%$. Potassium feldspars 


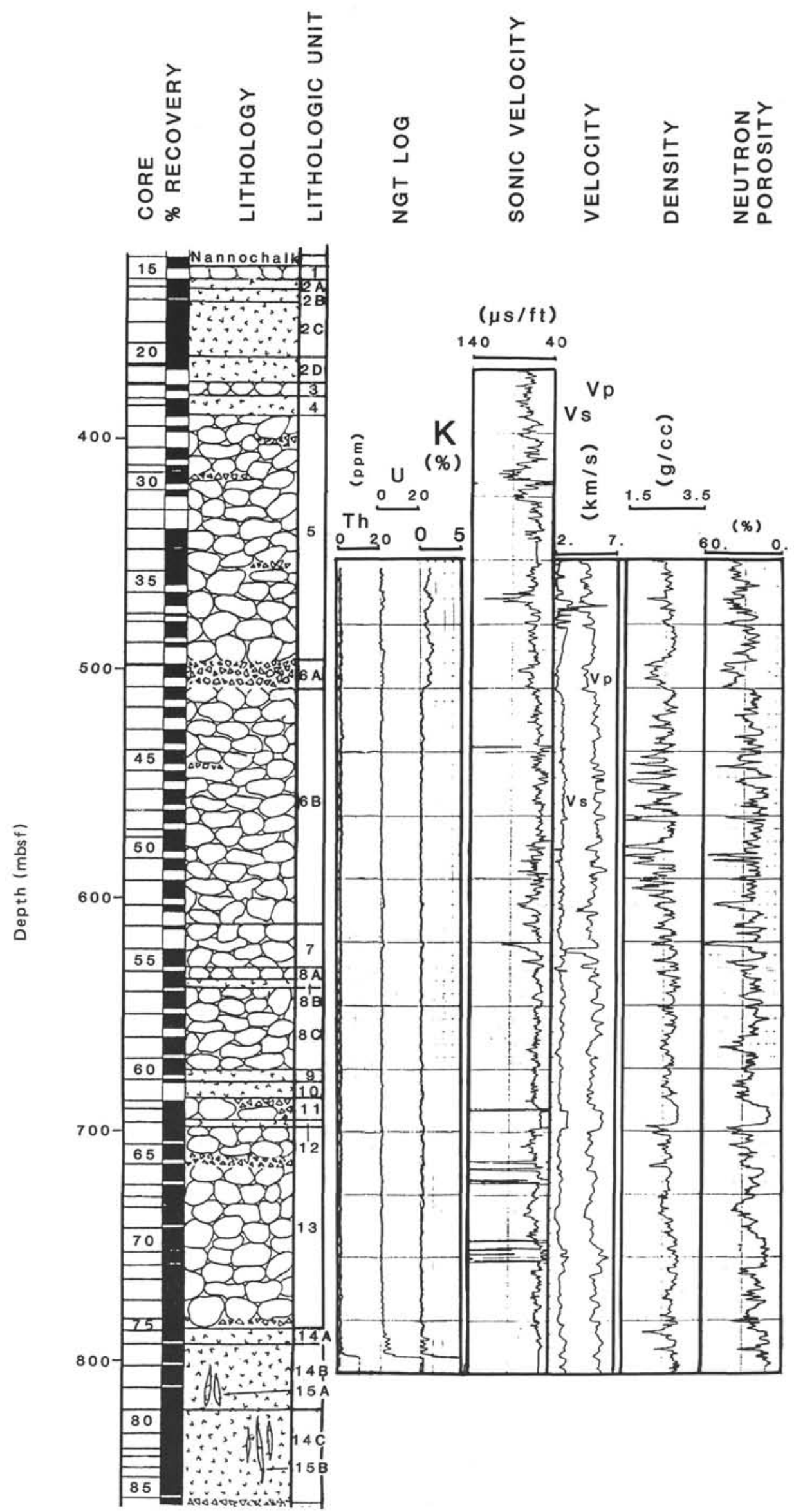

Figure 2. Summary of basement lithostratigraphy of DSDP Hole 418A with results of logging on ODP Leg 102. 
Table 1. Summary of basement lithologic units, DSDP Hole 418A.

\begin{tabular}{|c|c|c|c|c|c|c|}
\hline Unit & $\begin{array}{c}\text { Top }{ }^{a} \\
\text { (mbsf) }\end{array}$ & $\begin{array}{l}\text { Base }^{a} \\
\text { (mbsf) }\end{array}$ & $\begin{array}{l}\text { Thickness } \\
\text { (m) }\end{array}$ & $\begin{array}{l}\text { Type cooling } \\
\text { Unit }\end{array}$ & $\begin{array}{l}\text { Phenocryst } \\
\text { Assemblage }\end{array}$ & $\begin{array}{c}\text { Intervals } \\
\text { (Core-Section, cm) }\end{array}$ \\
\hline 1 & 324.0 & 329.6 & 5.6 & Pillow basalt & Plag-(Oliv) & $15-1,20$ to $16-1,10$ \\
\hline $2 \mathrm{~A}$ & 329.6 & 331.7 & 2.1 & Massive basalt & Plag-(Oliv) & $16-1,10$ to $16-2,105$ \\
\hline 2B & 331.7 & 339.0 & 7.3 & Massive basalt & Plag-(Oliv) & $16-2,105$ to $17-4,150$ \\
\hline $2 \mathrm{C}$ & 339.0 & 363.1 & 24.1 & Massive basalt & Plag-(Oliv) & $18-1,0$ to $20-5,81$ \\
\hline 2D & 363.1 & 376.6 & 13.5 & Massive basalt & Plag-(Oliv)-[Cpx] & $20-5,81$ to $24-1,57$ \\
\hline 3 & 376.6 & 383.3 & 6.7 & Pillow basalt & Plag-(Oliv)-[Cpx] & $24-1,57$ to $25-2,60$ \\
\hline 4 & 383.3 & 387.1 & 3.8 & Massive basalt & Plag-(Oliv)-[Cpx] & $25-2,60$ to $26-2,110$ \\
\hline 5 & 387.1 & 498.5 & 111.4 & $\begin{array}{l}\text { Pillow basalt and } \\
\text { breccia }\end{array}$ & Plag-(Oliv)-[Cpx] & $26-2,110$ to $40-3,47$ \\
\hline $6 \mathrm{~A}$ & 498.5 & 510.5 & 12.0 & Breccia & Plag-Oliv-(Sp)-[Cpx] & $41-1,0$ to $42-2,150$ \\
\hline $6 \mathrm{~B}$ & 510.5 & 611.0 & 100.5 & Pillow basalt & Plag-Oliv-(Sp)-[Cpx] & $42-3,0$ to $53-3,150$ \\
\hline 7 & 611.0 & 629.2 & 18.2 & Pillow basalt & Plag-Oliv-Cpx & $54-1,0$ to $55-7,70$ \\
\hline $8 \mathrm{~A}$ & 629.2 & 632.9 & 3.7 & Pillow basalt & Plag-Oliv-Cpx & $55-7,70$ to $56-3,45$ \\
\hline $8 B$ & 632.9 & 636.3 & 3.4 & Massive(?) basalt & Plag-Oliv-Cpx & $56-3,45$ to $56-5,125$ \\
\hline $8 \mathrm{C}$ & 636.3 & 671.8 & 35.5 & Pillow basalt & Plag-Oliv-Cpx & $56-5,125$ to $60-4,33$ \\
\hline 9 & 671.8 & 676.5 & 4.7 & $\begin{array}{l}\text { Massive, vesicular } \\
\text { basalt }\end{array}$ & Plag & $60-4,33$ to $60-6,66$ \\
\hline 10 & 676.5 & 686.0 & 9.5 & Massive basalt & Plag & $61-1,0$ to 61 bit, 95 \\
\hline 11 & 686.0 & 695.5 & 9.5 & Pillow basalt & Plag-Cpx-Oliv & $62-1,0$ to $63-5,119$ \\
\hline 12 & 695.5 & 698.2 & 2.7 & Massive(?) basalt & Plag-Cpx-Oliv & $64-1,0$ to $64-2,122$ \\
\hline 13 & 698.2 & 786.5 & 88.3 & $\begin{array}{l}\text { Pillow basalt and } \\
\text { breccia }\end{array}$ & Plag-Cpx-Oliv & $64-2,122$ to $75-4,150$ \\
\hline $14 \mathrm{~A}$ & 786.5 & 793.6 & 7.1 & Massive basalt & Plag-Cpx-Oliv & $75-5,0$ to $77-1,50$ \\
\hline 14B & 793.6 & 821.5 & 27.9 & Massive basalt & Plag-Cpx-Oliv & $77-1,50$ to $79-7,124$ \\
\hline $14 \mathrm{C}$ & 821.5 & 859.8 & 38.3 & Massive basalt & Plag-Cpx-Oliv & $80-1,0$ to $86-1,25$ \\
\hline $15 \mathrm{~A}$ & $b_{-}$ & - & - & Basalt dikes & Plag-Oliv-Cpx & $\begin{array}{l}79-1,75 \text { to } 79-1,110 \\
79-2,78 \text { to } 79-2,105 \\
79-3,105 \text { to } 79-4,95\end{array}$ \\
\hline $15 \mathrm{~B}$ & - & - & - & Basalt dikes & Plag-Oliv & $\begin{array}{l}80-2,117 \text { to } 80-3,127 \\
80-4,2 \text { to } 80-4,42 \\
80-4,107 \text { to } 80-5,110\end{array}$ \\
\hline 16 & 859.8 & 868.0 & 8.2 & $\begin{array}{l}\text { Pillow basalt and } \\
\text { breccia }\end{array}$ & Plag-Oliv-Cpx-Sp & $86-1,25$ to $86-6,55$ \\
\hline
\end{tabular}

a Depths corrected for spacers.
b Undetermined.

(all from DSDP Site 417) have an average of $16.2 \% \mathrm{~K}_{2} \mathrm{O}$, slightly less than the ideal of $16.9 \%$ (Humphris et al., 1980). Potassium feldspar can be found throughout the core, but is most abundant in lithologic Unit 5, Subunit 6A, and the uppermost part of Subunit 6B (Humphris et al., 1980; Pertsev and Rusinov, 1980). Three chemical analyses of identified phillipsite have $\mathrm{K}_{2} \mathrm{O}$ levels between $3.0 \%$ and $11.4 \%$ (Pertsev and Rusinov, 1980; Pritchard, 1980). Two apophyllite samples show good agreement in $\mathrm{K}_{2} \mathrm{O}$ level: $4.60 \%$ and $4.66 \%$ (Pertsev and Rusinov, 1980).

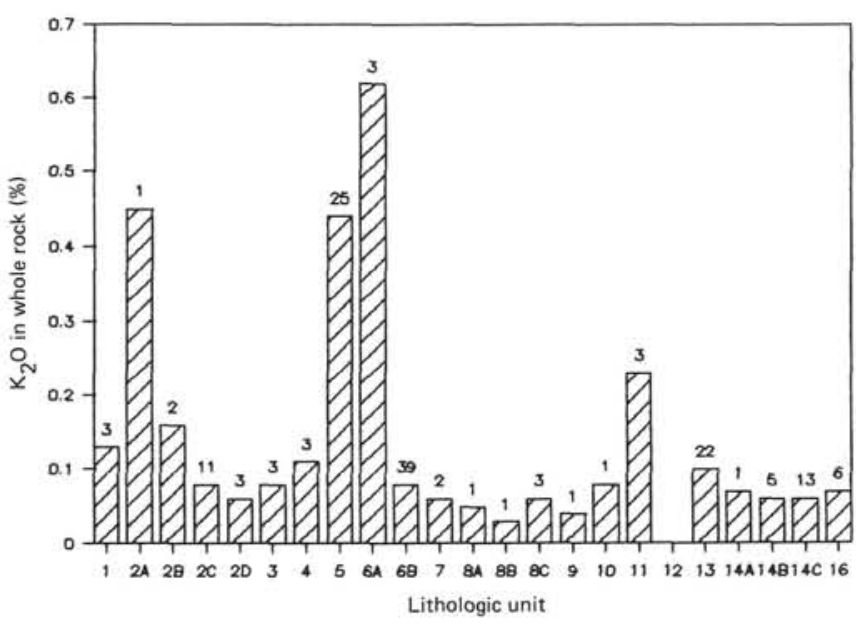

Figure 3. Average $\mathrm{K}_{2} \mathrm{O}$ in whole-rock samples, DSDP Hole 418A; results of Flower et al. (1980). Numbers above bars refer to number of samples analyzed in that interval.
Analcite has very low levels of $\mathrm{K}_{2} \mathrm{O}$ (less than $0.09 \%$; Mevel, 1980; Pritchard, 1980). Many unspecified zeolites that were chemically analyzed may be any of these identified zeolites: low $\mathrm{K}_{2} \mathrm{O}$ levels correspond to analcite or natrolite, moderate levels to apophyllite, and higher levels to phillipsite.

Two major types of clay reported as alteration products are distinguishable in thin section and by chemistry: (1) green clays, which range in color from bright to dark green, are the most widespread alteration product and generally have moderate $\mathrm{K}_{2} \mathrm{O}$ levels, from $4.79 \%$ to $7.55 \%$ (Table 2 ), and (2) brown clays that replace olivine phenocrysts, line vesicles and veins, and partly replace some plagioclase phenocrysts. These brown clays are low in $\mathrm{K}_{2} \mathrm{O}$, containing from $0.01 \%$ to $1.52 \%$ (Table 2 ).

\section{CURRENT STUDY}

\section{Methods}

Clay material of different colors was hand-picked from 30 samples taken from DSDP Hole 418A core using an X-ACTO knife and dental tools. Samples were taken mainly from the interval that gave high $\mathrm{K}$ readings on the Schlumberger NGT log. Where possible, clay of a single color was scraped onto glass slides, mixed with distilled water, and allowed to air dry. Where physical separation was not possible, the clay material was scraped all together, or, in the case of breccia matrix, gently ground to a fine powder, and mounted on glass slides as above. These mounts were then X-rayed using Ni-filtered $\mathrm{CuK} \alpha$ radiation (40 $\mathrm{kV}, 20 \mathrm{~mA}$ ), and a scan speed of $0.05^{\circ} / \mathrm{s}$ (1) from $2^{\circ}$ to $70^{\circ} 2 \theta$, untreated, and (2) from $2^{\circ}$ to $30^{\circ} 2 \theta$ after treatment with ethylene glycol for more than $1 \mathrm{hr}$ at $60^{\circ} \mathrm{C}$. Thin sections were made from well-indurated samples. Some of the core samples and thin sections were polished, coated with gold, and mounted for SEM analysis on a JEOL T330 with accelerating voltage of 20 or $30 \mathrm{kV}$ (noted on the micrographs). In addition, core samples, $\mathrm{X}$-ray mounts, and thin sections 
Table 2. Summary of chemical analyses of green clays and brown clays in DSDP Hole 418A altered basalts. Abundance in weight percent.

\begin{tabular}{|c|c|c|c|c|c|c|c|c|c|c|}
\hline Sample & Color, occurrence & $\mathrm{SiO}_{2}$ & $\mathrm{Al}_{2} \mathrm{O}_{3}$ & $\mathrm{TiO}_{2}$ & $\mathrm{FeO}$ & $\mathrm{MgO}$ & $\mathrm{CaO}$ & $\mathrm{Na}_{2} \mathrm{O}$ & $\mathrm{K}_{2} \mathrm{O}$ & $\mathrm{MnO}$ \\
\hline \multicolumn{11}{|l|}{ Humphris et al. (1980) } \\
\hline $33-2,124 \mathrm{~cm}$ & Green, vug & 50.94 & 4.98 & - & 22.62 & 3.90 & 0.74 & - & 7.41 & \\
\hline $52-4,75-80 \mathrm{~cm}$ & Green, vug & 52.22 & 1.89 & - & 23.12 & 6.09 & 0.39 & - & 7.66 & \\
\hline $52-4,75-80 \mathrm{~cm}$ & Green, vesicle & 50.71 & 3.22 & - & 23.48 & 5.31 & 0.58 & - & 7.55 & \\
\hline $30-3,35-38 \mathrm{~cm}$ & Bright green & 50.27 & 2.17 & - & 24.86 & 3.94 & 0.56 & - & 7.52 & \\
\hline $30-3,35-38 \mathrm{~cm}$ & Green & 52.36 & 1.72 & - & 20.33 & 7.86 & 0.40 & - & 7.30 & \\
\hline $52-4,75-80 \mathrm{~cm}$ & Green & 49.85 & 3.11 & - & 24.91 & 4.99 & 0.67 & - & 7.38 & \\
\hline $52-4,75-80 \mathrm{~cm}$ & Green & 50.63 & 3.13 & - & 21.99 & 6.93 & 0.59 & - & 7.37 & \\
\hline $52-4,75-80 \mathrm{~cm}$ & Green & 50.13 & 3.50 & - & 20.69 & 8.29 & 0.64 & - & 6.74 & \\
\hline $60-1,117-121 \mathrm{~cm}$ & Green & 49.47 & 2.42 & - & 25.37 & 4.08 & 0.73 & - & 6.75 & \\
\hline $60-1,117-121 \mathrm{~cm}$ & Dark green & 50.19 & 2.88 & - & 20.16 & 8.23 & 0.67 & - & 6.04 & \\
\hline \multicolumn{11}{|l|}{ Mevel (1980) } \\
\hline $38-3,4-6 \mathrm{~cm}$ & Green clay, vein & 48.09 & 7.55 & 0.05 & 24.37 & 4.77 & 0.44 & - & 5.33 & 0.12 \\
\hline $38-3,31-33 \mathrm{~cm}$ & Green clay, vein & 50.07 & 4.66 & - & 24.13 & 4.51 & 0.70 & - & 6.97 & 0.06 \\
\hline $38-3,50-52 \mathrm{~cm}$ & Green clay, vein & 49.61 & 6.39 & - & 21.49 & 7.25 & 1.35 & - & 5.78 & 0.04 \\
\hline $42-2,138-143 \mathrm{~cm}$ & Green clay, BPC & 49.86 & 9.08 & - & 20.74 & 6.61 & 0.68 & - & 5.25 & 0.14 \\
\hline $59-4,134-110 \mathrm{~cm}$ & Green clay, BPC & 51.26 & 7.99 & - & 19.53 & 5.69 & 0.12 & 0.20 & 5.73 & 0.09 \\
\hline $74-2,69-71 \mathrm{~cm}$ & Green clay, vein & 45.35 & 11.06 & 0.79 & 22.75 & 5.87 & 1.14 & - & 5.17 & 0.08 \\
\hline $86-2,91-94 \mathrm{~cm}$ & Green clay, BPC & 49.69 & 7.21 & - & 20.68 & 5.90 & 0.68 & - & 6.03 & 0.06 \\
\hline Scarfe (1980) & & & & & $\mathrm{Fe}_{2} \mathrm{O}_{3}$ & & & & & \\
\hline $55-2,48-50 \mathrm{~cm}$ & Green clay & 51.1 & 1.8 & & 27.3 & 5.3 & 2.1 & - & 7.3 & \\
\hline Average, green clays & & 50.10 & 4.71 & 0.05 & 21.50 & 5.86 & 0.73 & 0.01 & 6.63 & 0.07 \\
\hline \multicolumn{11}{|l|}{ Humphris et al. (1980) } \\
\hline $19-5,42-46 \mathrm{~cm}$ & Brown, oliv & 50.29 & 3.15 & - & 18.41 & 14.50 & 1.20 & 0.54 & 1.52 & \\
\hline $52-4,75-80 \mathrm{~cm}$ & Brown, oliv & 50.09 & 4.39 & - & 11.68 & 20.36 & 1.32 & 0.38 & 0.18 & \\
\hline $71-3,101-104 \mathrm{~cm}$ & Brown, vesicle & 46.42 & 6.93 & - & 15.22 & 17.69 & 2.49 & 0.40 & 0.12 & \\
\hline $71-3,101-104 \mathrm{~cm}$ & Brown, phenocryst & 46.83 & 6.95 & - & 14.91 & 17.34 & 1.96 & 0.38 & 0.09 & \\
\hline $30-3,35-38 \mathrm{~cm}$ & Light brown & 45.32 & 3.92 & - & 10.31 & 18.35 & 0.87 & - & 0.99 & \\
\hline $30-3,35-38 \mathrm{~cm}$ & Light brown & 45.39 & 4.11 & - & 10.34 & 18.55 & 0.95 & - & 0.78 & \\
\hline $30-3,35-38 \mathrm{~cm}$ & Dark brown & 44.54 & 4.03 & - & 9.55 & 19.30 & 1.06 & - & 0.16 & \\
\hline $52-4,75-80 \mathrm{~cm}$ & Dark brown & 45.53 & 5.23 & - & 12.61 & 18.22 & 1.16 & - & 0.56 & \\
\hline $60-1,117-121 \mathrm{~cm}$ & Dark brown & 45.63 & 5.46 & - & 14.12 & 18.27 & 1.61 & - & - & \\
\hline \multicolumn{11}{|l|}{ Mevel (1980) } \\
\hline $38-3,50-52 \mathrm{~cm}$ & Brown clay, vein & 42.37 & 8.02 & - & 16.01 & 18.01 & 1.72 & 0.03 & 0.16 & 0.04 \\
\hline $42-2,138-143 \mathrm{~cm}$ & Brown clay, vesicle & 45.98 & 8.52 & - & 13.04 & 20.25 & 0.52 & - & 0.02 & 0.07 \\
\hline $42-2,138-143 \mathrm{~cm}$ & Brown clay, vein & 43.02 & 8.00 & - & 9.31 & 20.88 & 0.34 & 0.03 & 0.02 & 0.05 \\
\hline $56-6,56-60 \mathrm{~cm}$ & Brown clay, vein & 43.85 & 7.19 & 0.23 & 16.94 & 18.45 & 0.88 & - & 0.02 & 0.05 \\
\hline $59-4,134-140 \mathrm{~cm}$ & Brown clay, brec & 44.56 & 5.98 & - & 12.01 & 19.61 & 0.37 & - & 0.02 & 0.08 \\
\hline $86-2,91-94 \mathrm{~cm}$ & Brown clay, vein & 44.23 & 7.85 & - & 13.06 & 20.81 & 0.35 & 0.06 & 0.01 & 0.05 \\
\hline Scarfe $(1980)$ & & & & & $\mathrm{Fe}_{2} \mathrm{O}_{3}$ & & & & & \\
\hline $65-1,108-110 \mathrm{~cm}$ & Brown clay & 43.9 & 3.2 & - & 15.6 & 18.5 & 1.7 & 2.9 & - & \\
\hline Average, brown clays & & 45.50 & 5.81 & 0.01 & 12.54 & 18.69 & 1.16 & 0.30 & 0.29 & 0.05 \\
\hline
\end{tabular}

Note: $\mathrm{BPC}=$ brecciated pillow crust; oliv $=$ replaced olivine phenocryst; brec $=$ breccia .

were observed under a Cambridge SEM equipped with a Princeton Gamma-Tech EDS for standardless spectral analyses.

\section{Results}

In hand specimen, the most abundant alteration product within lithologic Unit 5 and Subunit $6 \mathrm{~A}$ appears to be the dark green clay that fills veins and vesicles, forms the matrix of breccias, and coats altered basalt (pillow?) fragments. Palagonite is the second most abundant alteration product, followed by calcite, brown clay, potassium feldspar, zeolites, and bright green clay.

\section{Clays}

Diffraction results indicate that the dark green clay is composed of at least two expandable minerals (smectites) in most samples (Table 3 and Figs. 4 and 5). Most of the untreated samples give basal (001) spacings of from 12.2 to $13.0 \AA$ (most com- monly $12.8 \AA$ and from 14.1 to $15.0 \AA$ (Fig. 4A-4D). Five samples have another peak between 15.0 and $16.3 \AA$. Most commonly, the (001) peaks of glycol-treated samples occur at 16.7 to $17.3 \AA$ and at $15.4 \AA$ (Fig. 5A-5D). By comparing diffractograms with and without the sharp $12.8 \AA$ peak, it appears that one smectite has an approximately $13-\AA$ spacing that expands to approximately $15 \AA$ upon glycolation. The other smectite has an approximately $14.5-\AA$ peak, which expands to approximately $17 \AA$ upon glycolation. Sample $418 \mathrm{~A}-45-2$ shows regular interstratification by the presence of 19 - and $37-\AA$ peaks for the glycol-treated sample (Fig. 5D). Many of the glycol-treated samples give medium to weak (002), (003), and (005) peaks at 8.47 to $8.58,5.54$ to 5.62 , and 3.35 to $3.37 \AA$, respectively (Table 3 and Figs. 5A-5D). The position of the (060) peak (1.51 to $1.53 \AA$ ) indicates a dioctahedral and a trioctahedral mineral (Table 3). There is no $10-\AA$ peak that would correspond to celadonite. A 3.09- $\AA$ peak that corresponds to this mineral was noted in Sample 418A-31-2 (Fig. 4B). 
Table 3. Summary of X-ray diffraction results, Hole 418A. Spacing in angstroms ( $\AA$ ).

\begin{tabular}{|c|c|c|c|c|c|c|c|c|c|}
\hline \multirow[b]{2}{*}{ Sample } & \multicolumn{3}{|c|}{ Untreated } & \multicolumn{4}{|c|}{ Glycolated } & \multirow[b]{2}{*}{ Others } & \multirow[b]{2}{*}{ Mineralogy $y^{a}$} \\
\hline & $(001)$ & Others $^{\mathrm{a}}$ & $(060)$ & $(001)$ & $(002)$ & $(003)$ & $(005)$ & & \\
\hline $19-1,86-88 \mathrm{~cm}$ & $12.8 \mathrm{~b}$ & & $\begin{array}{l}1.516 \mathrm{~s} \\
1.511 \mathrm{~s} \\
1.505 \mathrm{~b}\end{array}$ & $\begin{array}{l}17.1 \mathrm{~b} \\
14.2 \mathrm{~b}\end{array}$ & $8.47 b$ & & $3.37 \mathrm{~b}$ & & \\
\hline $29-1,86-88 \mathrm{~cm}$ & $\begin{array}{l}14.1 \mathrm{w} \\
12.8 \mathrm{~s}\end{array}$ & & $1.501 w$ & $\begin{array}{l}17.5 \mathrm{~s} \\
15.5 \mathrm{~s}\end{array}$ & $8.58 w$ & & $3.37 \mathrm{~b}$ & & \\
\hline $30-3,84-89 \mathrm{~cm}$ & $\begin{array}{l}14.1 \mathrm{~m} \\
12.9 \mathrm{~m}\end{array}$ & & $1.514 \mathrm{w}$ & $\begin{array}{l}17.3 \mathrm{~s} \\
13.1 \mathrm{w}\end{array}$ & & & & $3.28,2.17$ & $\mathrm{~K}$-feldspar \\
\hline $31-2,34-36 \mathrm{~cm}$ & $\begin{array}{l}14.1 \mathrm{w} \\
12.8 \mathrm{~s}\end{array}$ & $* 10.6 \mathrm{w} * 3.09 \mathrm{~m}$ & - & $\begin{array}{l}17.2 \mathrm{~s} \\
15.4 \mathrm{w}\end{array}$ & $8.45 \mathrm{~m}$ & $5.61 w$ & $3.36 \mathrm{~m}$ & & *Celadonite \\
\hline $33-2,35-37 \mathrm{~cm}$ & $\begin{array}{l}15.5 \mathrm{~m} \\
14.5 \mathrm{~m} \\
12.6 \mathrm{~s}\end{array}$ & & $1.517 \mathrm{~s}$ & $16.9 \mathrm{~s}$ & $8.41 \mathrm{~m}$ & & $3.35 \mathrm{~m}$ & 3.23 & K-feldspar \\
\hline $34-1,27-29 \mathrm{~cm}$ & $12.6 \mathrm{vw}$ & & $1.520 \mathrm{w}$ & $17.0 \mathrm{~s}$ & $8.47 \mathrm{~m}$ & $5.62 w$ & $3.37 \mathrm{~m}$ & 3.23 & $\mathrm{~K}$-feldspar \\
\hline $34-1,95-98 \mathrm{~cm}$ & $\begin{array}{l}14.5 \mathrm{~m} \\
13.6 \mathrm{~m}\end{array}$ & & - & $17.0 \mathrm{~s}$ & $8.42 w$ & & & & \\
\hline $34-2,80-82 \mathrm{~cm}$ & $\begin{array}{l}14.2 \mathrm{w} \\
13.0 \mathrm{~s}\end{array}$ & & - & $17.3 \mathrm{~s}$ & $8.59 \mathrm{~m}$ & & $3.37 \mathrm{~m}$ & 3.23 & K-feldspar \\
\hline $34-3,51-53 \mathrm{~cm}$ & $\begin{array}{l}15.0 \mathrm{w} \\
12.7 \mathrm{~s}\end{array}$ & $3.11(005 ?)$ & - & $17.1 \mathrm{~s}$ & $8.49 \mathrm{~m}$ & & $3.38 \mathrm{~m}$ & 3.18 & K-feldspar? \\
\hline $34-5,55-60 \mathrm{~cm}$ & $12.8 \mathrm{~s}$ & $4.61(003 ?)$ & $1.540 \mathrm{w}$ & $\begin{array}{l}16.8 \mathrm{~s} \\
15.4 \mathrm{w}\end{array}$ & $8.41 \mathrm{~m}$ & $5.54 w$ & $3.35 \mathrm{~m}$ & & \\
\hline $\begin{array}{l}35-1,38-43 \mathrm{~cm} \\
36-3,15-20 \mathrm{~cm}\end{array}$ & & & & & & & & $\begin{array}{l}3.03,3.21 \\
3.24\end{array}$ & $\begin{array}{l}\text { Calcite, K-feldspar } \\
\text { K-feldspar }\end{array}$ \\
\hline $36-4,20-21 \mathrm{~cm}$ & $\begin{array}{l}14.1 \mathrm{w} \\
12.9 \mathrm{~s}\end{array}$ & & $\begin{array}{l}1.532 \mathrm{w} \\
1.503 \mathrm{~b}\end{array}$ & $17.2 \mathrm{~s}$ & $8.52 \mathrm{~m}$ & & $3.37 w$ & & \\
\hline $36-5,122-125 \mathrm{~cm}$ & $\begin{array}{l}14.5 w \\
12.7 w\end{array}$ & & $1.500 \mathrm{w}$ & $17.0 \mathrm{~m}$ & & & & & \\
\hline $38-3,66-69 \mathrm{~cm}$ & $12.2 \mathrm{vs}$ & & $1.512 w$ & $17.3 \mathrm{vs}$ & $8.49 \mathrm{~m}$ & & $3.38 w$ & & \\
\hline $38-5,127-130 \mathrm{~cm}$ & $13.2 \mathrm{~b}$ & & - & $17.3 w$ & & & & & \\
\hline $39-1,72-76 \mathrm{~cm}$ & $\begin{array}{l}16.3 \mathrm{~m} \\
14.7 \mathrm{w} \\
12.3 \mathrm{w}\end{array}$ & & - & $16.8 w$ & & & & 3.252 .57 & $\mathrm{~K}$-feldspar \\
\hline $40-2,13-17 \mathrm{~cm}$ & $12.8 \mathrm{vw}$ & $4.52 w(003 ?)$ & - & $17.0 \mathrm{w}$ & & & & 3.272 .57 & $\mathrm{~K}$-feldspar \\
\hline $41-1,17-22 \mathrm{~cm}$ & $14.2 \mathrm{w}, \mathrm{b}$ & $4.55 w(003 ?)$ & - & $17.3 \mathrm{~m}$ & & & & & \\
\hline $41-1,136-140 \mathrm{~cm}$ & $\begin{array}{l}14.1 \mathrm{w} \\
12.6 \mathrm{w}\end{array}$ & & - & $\begin{array}{l}17.0 \mathrm{w} \\
15.4 \mathrm{w}\end{array}$ & & & & & \\
\hline $\begin{array}{l}41-3,113-118 \mathrm{~cm} \\
\text { breccia matrix }\end{array}$ & $\begin{array}{l}14.1 \mathrm{w} \\
12.8 \mathrm{w}\end{array}$ & ${ }^{t} 5.66$ & - & $\begin{array}{l}17.3 \mathrm{~s} \\
15.3 \mathrm{~m}\end{array}$ & & & & $38^{* *}$ & ${ }^{t}$ Analcite, ${ }^{*}$ mixed-layer \\
\hline $42-1,57-61 \mathrm{~cm}$ & & ${ }^{t} 5.60^{t} 3.43$ & & & & & & & ${ }^{\text {t} A n a l c i t e ~}$ \\
\hline $45-2,40-44 \mathrm{~cm}$ & $\begin{array}{l}14.4 \mathrm{~m} \\
12.5 \mathrm{~m}\end{array}$ & ${ }^{t} 5.61$ & - & $\begin{array}{l}16.7 \mathrm{~s} \\
15.2 \mathrm{w}\end{array}$ & & & & $37, * * 19 * *$ & ${ }^{\text {t} A n a l c i t e, ~}{ }^{* *}$ mixed-layer \\
\hline $47-3,95-98 \mathrm{~cm}$ & $\begin{array}{l}14.0 \mathrm{~m} \\
12.7 \mathrm{~m}, \mathrm{~s}\end{array}$ & & - & $17.0 \mathrm{~s}$ & $\begin{array}{l}8.51 \mathrm{~m} \\
8.42 \mathrm{~m}\end{array}$ & & $\begin{array}{l}3.37 w \\
3.35 w \\
3.34 w\end{array}$ & & \\
\hline $51-4,27-29 \mathrm{~cm}$ & $\begin{array}{l}15.9 \mathrm{w} \\
12.9 \mathrm{~s}\end{array}$ & $3.12(005 ?)$ & $1.538 w$ & $17.8 \mathrm{~s}$ & $8.59 \mathrm{~m}$ & & $3.37 w$ & & \\
\hline $55-2,26-30 \mathrm{~cm}$ & $\begin{array}{l}16.0 \mathrm{~b} \\
13.5 \mathrm{~m}\end{array}$ & $3.34(?)$ & - & $17.0 \mathrm{vs}$ & $8.49 \mathrm{~m}$ & & $3.36 \mathrm{w}$ & 3.21 & $K$-feldspar \\
\hline $58-1,41-43 \mathrm{~cm}$ & $12.6 \mathrm{vs}$ & 3.14 (005?) & - & $17.0 \mathrm{vs}$ & $8.59 b$ & & $3.37 w$ & & \\
\hline
\end{tabular}

Note: $\mathrm{b}=$ broad $; \mathrm{m}=$ medium; $\mathrm{s}=$ sharp; $\mathrm{v}=$ very; $\mathrm{w}=$ weak.

a tand $* *$ relate measurements to mineralogy.

When viewed with the SEM, the X-ray mounts of dark green clay (smectite) have unoriented, radiating masses of laths that combine in upward-projecting "hubs" (Pl. 2, Figs. 1 and 2). These lath-shaped minerals were seen in many fracture sections, and a representative spectral analysis indicates that this material is rich in $\mathrm{Si}$ and $\mathrm{Fe}$, with less $\mathrm{Mg}, \mathrm{Al}$, and $\mathrm{Ca}$ (Pl. 2, Figs. 3 and 4). Potassium was not detected in these laths. The laths are up to $68 \mu \mathrm{m}$ long and often occur in radiating masses filling cavities of fracture sections (Pl. 3, Figs. 1 and 2).

These radiating laths are seen often in thin section, filling veins, vesicles, and holes left by olivine dissolution (PI. 3, Fig. 3). This mineral may be brown (usually in the center) to any shade of green. Individual laths are generally up to $5 \mu \mathrm{m}$ wide, have blunt or pointed terminations, and may be split to give a flaky appearance (Pl. 3, Figs. 4 and 5). In larger cavities (in this case, probably a fracture) the terminations are altered to a new phase with a coarse, platy appearance (Pl. 3, Fig. 6). Similar material has been reported from deep-sea basalt and identified (by microprobe analysis) as iddingsite by Honnorez et al. (1983). Iddingsite is an alteration product of saponite and con- sists of smectite in intimate mixture with goethite (Baker and Haggerty, 1967).

Celadon-green clays were observed in thin section but never in great enough quantity to obtain a pure XRD mount (Pl. 1, Figs. 4 through 6). Under the SEM these clays appear as tiny plates or flakes, generally $1 \mu \mathrm{m}$ or smaller. In Sample 418A-58-1, this same material appears to have replaced a partly resorbed olivine phenocryst (Pl. 4, Fig. 1), with the flakes finest around the rim of the void and gradually becoming coarser (up to $5 \mu \mathrm{m}$ ) toward the core (Pl. 4, Figs. 2 and 3). Spectral analysis indicates that the fine material is high in $\mathrm{K}, \mathrm{Fe}$, and $\mathrm{Mg}$ (Pl. 4, Figs. 4 and 5). The coarser-grained material at the center is slightly more enriched in $\mathrm{MgO}$ (by $4 \%$ ), $\mathrm{CaO}$ (by $0.4 \%$ ), and $\mathrm{Al}_{2} \mathrm{O}_{3}$ (by $1 \%$ ) and has $1 \%$ less $\mathrm{K}_{2} \mathrm{O}$ and $4 \%$ less $\mathrm{FeO}^{\circ}$ (oxidation state not determined). The structural formulas of the rim and core clays (as determined by standardless spectral analysis) are $\left(\mathrm{K}_{0.485} \mathrm{Ca}_{0.065}\right)$ $\left(\mathrm{Fe}^{*}{ }_{1.585} \mathrm{Mg}_{0.735} \mathrm{Al}_{0.295}\right)\left(\mathrm{Si}_{3.86} \mathrm{Al}_{0.14}\right) \mathrm{O}_{10}(\mathrm{OH})_{2}$ outer rim and $\left(\mathrm{K}_{0.365}\right.$ $\left.\mathrm{Ca}_{0.09}\right)\left(\mathrm{Fe}^{*}{ }_{10.30} \mathrm{Mg}_{1.13} \mathrm{Al}_{0.28}\right)\left(\mathrm{Si}_{3.765} \mathrm{Al}_{0.235}\right) \mathrm{O}_{10}(\mathrm{OH})_{2}$ core. These formulas correspond more closely to green than to brown clays (Table 2). The smaller flakes may be the "proto-celadonite" of Legs 

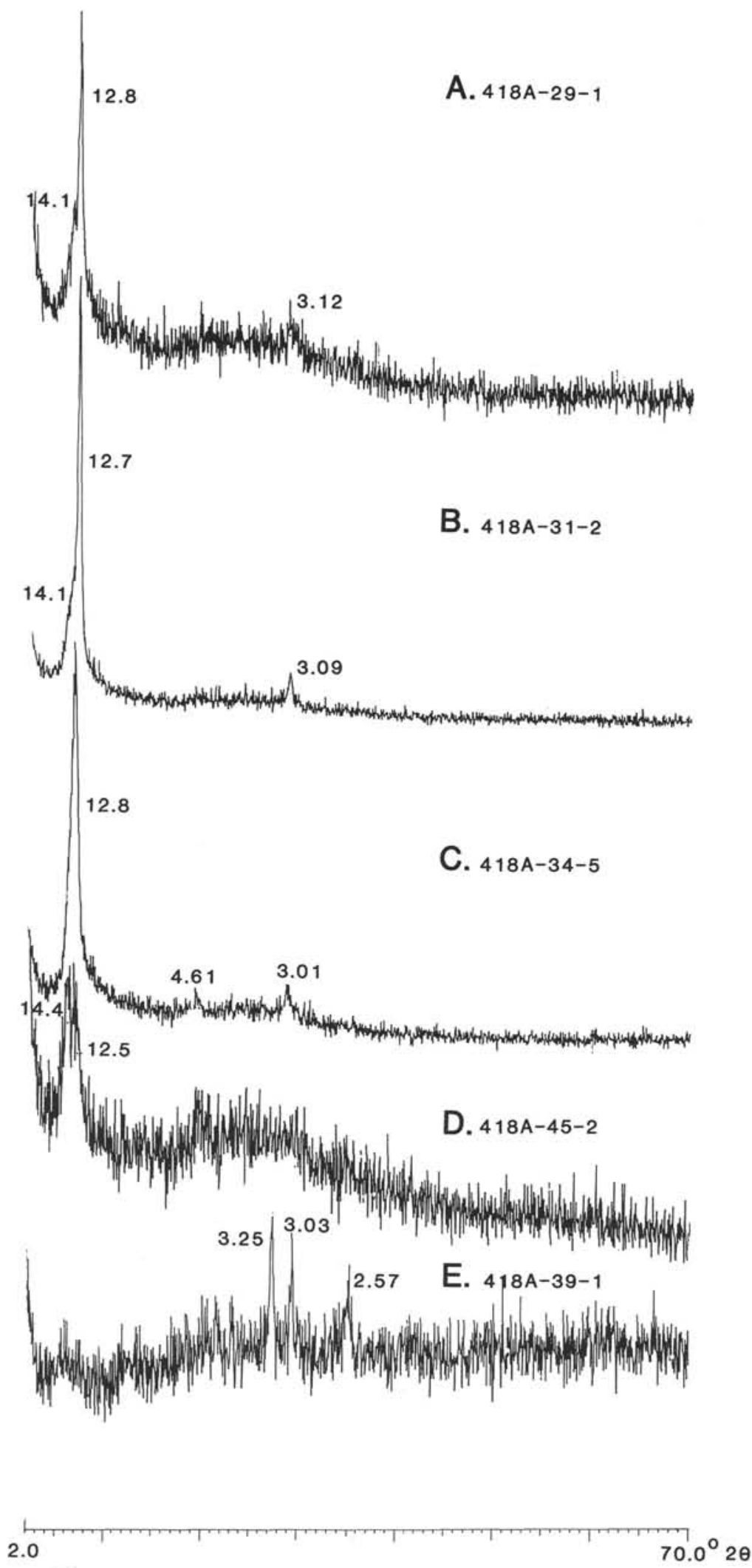

Figure 4. Diffraction results, untreated samples. A. Medium 14.1- and sharp 12.8- $\AA$ peaks; possibly saponite (14.1) and nontronite (12.8). 3.12- $\AA$ peak may be a higher order basal peak of saponite. B. 3.09- $\AA$ peak of celadonite(?). C. The peak at $4.61 \AA$ may be a higher-order basal peak of saponite. D. Diffractogram of regularly interstratified mixed-layer mineral. E. $3.25-$ and $2.57-\AA$ peaks of potassium feldspar; $3.03-\AA$ peak belongs to calcite. 


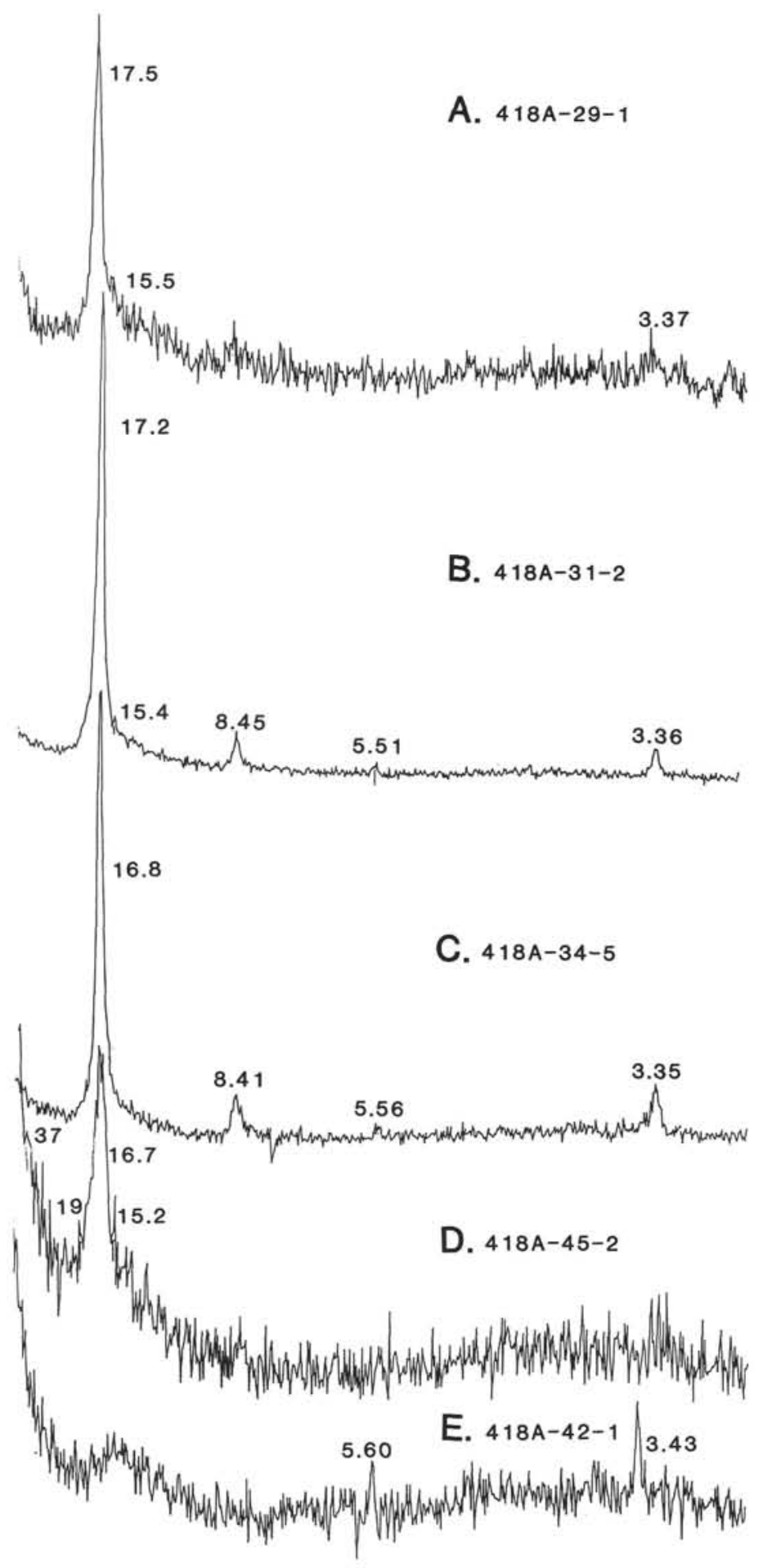

2.0 $30.0^{\circ} 2 \theta$

Figure 5. Diffraction results, samples treated with ethylene glycol. A. Sharp 17.5and weak $3.37-\AA$ peaks of saponite; weak $15.5-\AA$ peak of nontronite or mixed-layer nontronite-celadonite. B. 17.2-, 8.45-, 5.51-, and 3.36- $\AA$ peaks of saponite; $15.4-\AA$ peak of nontronite or mixed-layer nontronite-celadonite. C. All peaks of saponite. D. Regularly interstratified mixed-layer mineral with peaks at 37 - and $19-\AA$. E. 5.60and $3.43-\AA$ peaks of analcite. 
51,52 , and 53. The formulas indicate that either these minerals have vacant trioctahedral positions, their interlayer spaces are occupied by $\mathrm{Fe}$ oxides-hydroxides, or some of the $\mathrm{Mg}$ and/cr $\mathrm{Fe}$ may be on the exchange complex. A fracture partly bridged by laths passes through the core of a replaced phenocryst (Pl. 4, Fig. 4). A re-examination of all "lathy" samples in thin section and under the SEM revealed that, in all cases, the laths have grown outward from the finer grained material lining the walls of veins, vesicles, and fractures in a continuum of growth.

\section{Other Minerals}

Analcite (Fig. 5E) and potassium feldspar (Fig. 4E) are present in several samples (Table 3). Plagioclase feldspar was observed in thin section (Pl. 1, Figs. 2 and 3 ) and in diffraction analysis (3.18- $\AA$ peak). In samples from lithologic Unit 5, plagioclase is partly altered to potassium feldspar, especially in the outer rims. In Sample 418A-39-1, 72-76 cm, incipient alteration of plagioclase to a K-rich phase (potassium feldspar) and loss of $\mathrm{Ca}$ were observed using spectral analysis (Pl. 5, Figs. 1-3). Potassium feldspar was observed in almost every thin section from lithologic Unit 5 as a pale yellow alteration of plagioclase phenocrysts. Its presence was confirmed in thin sections from this interval by XRD (3.23- to $3.28-\AA$ peak). In some places plagioclase may be altered to a brown clay (Pl. 1, Fig. 3) that has a platy appearance under the SEM (Pl. 5, Fig. 4). This mineral may be a different phase from those discussed for veins, vesicle fillings, and olivine replacement but cannot be reliably distinguished on the basis of morphology. It is possibly a montmorillonite because it is forming in a more Al-rich environment than the other clays, but this is unsubstantiated by chemical analysis at this time.

\section{DISCUSSION}

\section{K-Bearing Phases and NGT Log}

The major phases contributing to the high $\mathrm{K}_{2} \mathrm{O}$ readings on the NGT include potassium feldspar, palagonite, and K-rich clay. The brown clay with low $\mathrm{K}$ content presumably contributes little to the signal. The following is an estimate of the contribution of each of these phases to the NGT log for lithologic Unit 5.

\section{Feldspar Contribution}

Lithologic Unit 5 was estimated to have $8 \%$ plagioclase phenocrysts as an average, with a maximum of $15 \%$ (Table 1; Shipboard Scientific Parties, 1980). A rough estimate is that as much as $25 \%$ of these phenocrysts has been altered to potassium feldspar. Thus, an average of approximately $2 \%$ of the rock ( $8 \%$ total plagioclase $\times 0.25$ altered $=2 \%$ potassium feldspar) is now potassium feldspar. The maximum amount of potassium feldspar is about $4 \%$ of the rock $(15 \%$ total plagioclase $\times 0.25$ altered $=3.75 \%$ potassium feldspar). The measured content of $\mathrm{K}$ in potassium feldspar of Hole $418 \mathrm{~A}$ basalt is $16 \%$. The level of $\mathrm{K}$ in bulk rock should average

0.02 potassium feldspar volume $\times 16 \% \mathrm{~K}=0.32 \% \mathrm{~K}$,

and have a maximum

0.04 potassium feldspar volume $\times 16 \% \mathrm{~K}=0.64 \% \mathrm{~K}$.

\section{Palagonite Contribution}

Humphris et al. (1980) estimated that no more than $20 \%$ of the Hole 418A core was altered; however, lithologic Unit 5 is conspicuously more altered than the average of the core as a whole-perhaps $25 \%$. The average $\mathrm{K}$ content of palagonite from 18 samples from DSDP Holes 417A, 417D, and 418A by three different workers is $1.46 \% \mathrm{~K}$; the maximum level is $3.39 \% \mathrm{~K}$. The palagonite contribution to the $\mathrm{K}$ signal should average

$$
0.25 \text { palagonite volume } \times 1.46 \% \mathrm{~K}=0.36 \% \mathrm{~K} \text {. }
$$

\section{K-Rich Clay Contribution}

The K-rich clay in veins and vesicles ("proto-celadonite" of Legs 51, 52, and 53) represents a small portion of the bulk rock-no more than $1 \%$ or $2 \%$ - but perhaps as much as $10 \%$ of breccias. An estimate of $2 \%$ will be used for lithologic Unit 5 . In this calculation, the few zeolites with slightly higher $\mathrm{K}$ content are included. At $5.4 \% \mathrm{~K}$ content in K-rich clay, the contribution of clay to the $\mathrm{K}$ signal would be an average

$$
0.02 \text { clay volume } \times 5.4 \% \mathrm{~K}=0.11 \% \mathrm{~K} \text {, }
$$

to a maximum

$$
0.10 \text { clay volume } \times 5.4 \% \mathrm{~K}=0.54 \% \mathrm{~K} \text {. }
$$

Summed together, the various contributors will give signals that equal an average

$$
(0.32+0.36+0.11)=0.79 \% \mathrm{~K}
$$

to a maximum

$$
(0.64+0.36+0.54)=1.54 \% \mathrm{~K} .
$$

The $\mathrm{K}$ readings from the NGT log in this interval (lithologic Unit 5) varied from a minimum of $0.3 \%$ to a maximum of $1.5 \% \mathrm{~K}$. According to these estimates, potassium feldspar accounts for roughly $40 \%$ of the $\mathrm{K}$ signal, palagonite for approximately $25 \%$ to $50 \%$, and K-rich clay for approximately $15 \%$ to $30 \%$. None of the phases occurring alone could account for the highest readings on the NGT log.

The amounts that each of these phases will contribute to NGT logs from other holes drilled in deep-sea basalt will vary depending on the type of alteration encountered at that location. Submarine weathering and alteration of basalts is extremely variable over a distance of a few kilometers, as illustrated by the results of DSDP Legs 51 to 53. The basalts recovered from nearby DSDP Hole 417A have undergone extensive oxidative alteration, which is observed on only a small scale at Hole 418A. The oxidized interval in Hole 418A is the same interval that gave high $\mathrm{K}$ readings on the NGT log. Potassium feldspar appears to be a late-stage phase formed in the process of submarine basalt weathering, as it is most abundant in the most altered basalts and least abundant in the freshest (Donnelly et al., 1980).

\section{Pore-Fluid Evolution at DSDP Hole 418A: Evidence for Continuous and Discontinuous Stages}

In all, three morphologic types of clay were seen with the SEM: (1) very small flakes, most around $1 \mu \mathrm{m}$ wide; (2) long laths, up to $5 \mu \mathrm{m}$ wide and $68 \mu \mathrm{m}$ long; and (3) curly flakes up to $5 \mu \mathrm{m}$ wide. Type 1 , the very small flakes, is $\mathrm{K}-$ and Fe-rich. They were the first clays to form as indicated by their occurrence as the first lining of many cavity walls. Their formation occurred after an initial phase of iron oxidation. Fe oxide-hydroxides often precede the clays as linings of cavities (Pl. 1, Figs. 4-6). Olivine was dissolved after or during iron oxidation and before the first clays formed (Pl. 1, Fig. 5, and Pl. 4, Fig. 1; see also Humphris et al., 1980; Pertsev and Rusinov, 1980; Mevel, 1980). Type 1 clays correspond to the green clays of Table 2. These clays were called "proto-celadonite" on DSDP Legs 51-53 because of $\mathrm{K}$ contents lower than the ideal for celadonite. Their color under the microscope is a light to bright green, 
grading to a dark green away from void walls as crystal size increases. They have a very fine, platy morphology similar to that reported for nontronite (Welton, 1984). The basal spacings of this clay are similar to those of the Garfield, Washington, nontronite (laboratory standard) but somewhat larger than others reported for nontronite (JCPDS, 1980; Bischoff, 1972). The cation content indicates that this clay is either partly tri- and partly dioctahedral or has Fe oxide-hydroxides in interlayer spaces. There may be some domain segregation, as Decarreau et al. (1987) observed in Ni-Fe-Mg smectites, with trioctahedral and dioctahedral domains within a continuous crystal lattice. The (060) reflections do not help to distinguish whether Fe-rich smectites are di- or trioctahedral (Russell and Clark, 1978). The type 1 clays are tentatively identified as nontronite based on chemical analysis, morphology, deficiency in octahedral cations, and high $\mathrm{K}$ content, which is not characteristic of saponite.

Type 2 clay, the long laths, also occurs in various shades of green and yellow in thin section, usually from celadon-green to very dark green and often brown toward the centers of voids. These are always associated with type 1 clay and always occur in the centers of pore and vein fillings. This type is very low in potassium and richer in $\mathrm{Mg}, \mathrm{Al}$, and $\mathrm{Ca}$ than type 1 clay. It probably corresponds to the brown clays of Table 2 , which are most often identified as saponite. The morphology is similar to that reported for saponite (Honnorez et al., 1983), although celadonite, nontronite, and $\mathrm{Fe}$-saponite all occur as laths (Sudo et al., 1981; Mering and Oberlin, 1971). The (001) spacings are similar to those reported for iron-rich saponite (Suquet et al., 1977; Thorez, 1976). Higher-order basal peaks on several diffractograms are more indicative of saponite (JCPDS, 1980). This clay may be saponite or it may be some Fe-rich smectite that is transitional between dioctahedral, ferric nontronite and trioctahedral, ferrous saponite. It is tentatively identified as saponite based on higher order basal spacings, lathy morphology, and low $\mathrm{K}$ content. At the centers of very large cavities, the saponite laths are modified to the thick plates of iddingsite (Pl. 1, Fig. 5, and Pl. 3, Fig. 5).

Type 3 clay is almost always some shade of brown in thin section. This is the form that replaces plagioclase feldspar. From the results of Table 2, it would appear that this form is lowest in $\mathrm{K}$ of the three clay types. It has not been observed in direct association with types 1 and 2 and is possibly a montmorillonite.

The different mineral phases, particularly types 1 and 2, cannot be distinguished on the basis of color and so cannot be quantified on this basis. Anderson and Stucki (1979) demonstrated that nontronite can be yellow, green, blue-green, or black, depending on the oxidation state and coordination number of its constituent iron. The radiating fibers of what is mostly saponite appear in thin section to be green, brown, or yellow. They are brown where later oxidation has altered saponite to iddingsite. The iddingsite is brown in thin section.

It is most significant that the type 1 clay becomes coarser in size toward the center of cavities (from less than 1 to $5 \mu \mathrm{m}$ ) until it forms long laths in the centers of the larger veins, vesicles, and holes left by dissolved olivine (Pl. 1, Figs. 1, 4, and 5, and Pl. 4, Fig. 4). There is a continuum of growth in the crystal, with an increase in size and a later change in morphology (Pl. 4, Figs. 2 and 4). This morphologic change is accompanied by a continuous change in chemistry (Pl. 4, Figs. 3 and 5) marked by a decrease in the lattice charge and $\mathrm{K}$ content and an increase in $\mathrm{Mg}, \mathrm{Al}$, and $\mathrm{Ca}$ going from cavity walls to cavity centers. This smooth transition is also shown by the data of Humphris et al. (1980). The type 1 clays may be celadonite, potassic nontronite, or perhaps mixed-layer nontronite-celadonite. The major difference between nontronite and celadonite is in the strength of the lattice charge developed by ionic substitution of $\mathrm{Al}$ and $\mathrm{Fe}^{+3}$ for $\mathrm{Si}$ in the tetrahedral layer, and of $\mathrm{Mg}$ and $\mathrm{Fe}^{+2}$ for $\mathrm{Fe}^{+3}$ in the octahedral layers (in addition to $\mathrm{K}$ content). Celadonite has the higher charge, and this charge is satisfied by interlayer $\mathrm{K}$, which causes a collapse of $15-\AA$ spacings to $10 \AA$. Nontronite is a potassiphilic smectite, which preferentially takes up potassium as an exchangeable cation; an increasingly K-rich series leads to celadonite (Velde, 1985). Whether celadonite s.s. actually forms first depends upon the availability of charge-generating substituting ions at the time of formation, which may depend upon the extent of Fe release and local redox potential during initial stages of $\mathrm{Fe}$ oxide-hydroxide formation. This initial stage of iron release is highly variable within the basalt pile, as indicated by the variable presence or absence of the iron oxide-hydroxide rim.

Whether celadonite, mixed-layer celadonite-nontronite, or potassic nontronite formed as the first clay mineral, the fluid from which it precipitated became increasingly depleted in $\mathrm{K}$ and $\mathrm{Fe}$ and increasingly enriched in $\mathrm{Mg}$ and $\mathrm{Ca}$. The transition was not a step-wise, discontinuous process but smooth in its progression, which indicates a closed, evolving system. At some point after celadonite precipitated locally, there was not enough charge generated in the neoforming lattice, $\mathrm{K}$ levels in the fluid declined, and a fully expandable smectite phase formed. This clay is the dioctahedral nontronite. By this time the fluid was reducing or nearly so, as Harder (1978) was able to synthesize nontronite at low temperatures only from reducing solutions. As nontronite continued to form it was increasingly enriched in $\mathrm{Al}$ and $\mathrm{Mg}$, which indicates that the ferric iron level in the fluid may control the lattice charge. Precipitation continued until some critical point was reached where $\mathrm{K}$ was very low and $\mathrm{Mg}$ was enriched, and the type 2 clay laths began to form. The larger crystal size of the laths indicates that the rate of precipitation decreased or that the growth of a few crystallites outpaced others. The type 2 clay is most likely Fe-saponite, a trioctahedral smectite. The iron in iron-rich saponite is ferrous, indicating that the fluid had become reducing during its evolution in the rock. Saponite, pyrite, calcite, and zeolites (Humphris et al., 1980) appear to be the end products of this evolved fluid.

At the very center of larger cavities, particularly in lithologic Unit 5 and Subunit $6 \mathrm{~A}$, the long saponite laths are oxidized to iddingsite. This indicates that fresh, or at least oxidizing, fluid moved through the basalt at a later time. The transformation of nontronite or saponite into iddingsite releases silica, which explains the fact that quartz and chalcedony appear among the last-forming phases in this interval (Humphris et al., 1980). This new fluid had enough $\mathrm{K}$ that plagioclase in this interval was altered to potassium feldspar. This accounts for the occurrence of most of the potassium feldspar in the oxidized interval (see also Humphris et al., 1980; Pertsev and Rusinov, 1980). The release of $\mathrm{Ca}$ from plagioclase and saponite could allow a second stage of calcite to form.

The second stage of oxidative alteration is confined to zones of high permeability: the breccia of lithologic Subunit $6 \mathrm{~A}$ and a breccia-pillow basalt of lithologic Unit 5. In addition, Humphris et al. (1980) observed another zone of secondary alteration, as indicated by the presence of iron oxide-hydroxides and high $\mathrm{K}_{2} \mathrm{O}$ content, from 667 to 725 mbsf. The NGT log shows slightly elevated $\mathrm{K}$ levels in this interval (Fig. 2). The lower part of this interval has several brecciated layers. These intervals must have served as conduits for a freshened supply of some oxidizing fluid.

\section{SUMMARY AND CONCLUSIONS}

High $\mathrm{K}$ readings observed on wireline logs run in basement can be attributed to extensive low-temperature oxidative alteration in general. Where these readings are accompanied by high porosity, low density, and low velocity readings, a breccia (Broglia and Moos, this volume) with a once-glassy matrix largely altered to K-rich clays (celadonite and/or potassic nontronite) may be inferred. These are products of an initial stage of low- 
temperature oxidative alteration. Where porosity, density, and velocity readings indicate no breccia, high $\mathrm{K}$ readings may be attributed to potassium feldspar occurrence, an indicator of a second stage of oxidative alteration. In either case there is a significant contribution to the $\mathrm{K}$ reading from palagonite.

The sequence of weathering in Hole $418 \mathrm{~A}$ basalts as originally proposed by Humphris et al. (1980), Pertsev and Rusinov (1980), and Mevel (1980) is corroborated by the results of this study, with the additional observations that the initial K-rich clay mineral may be anything from celadonite through a mixed-layer celadonite/nontronite to a potassic nontronite and that the precipitated phases form a continuum in chemical content from an initial dioctahedral $\mathrm{K}$ - and $\mathrm{Fe}^{+3}$-rich phase through intermediate $\mathrm{Mg}>\mathrm{Al} \gg \mathrm{Ca}$ (as interlayer cation) phases, ending with a $\mathrm{Mg}-\mathrm{Fe}^{+2}$ trioctahedral saponite. The phases are so continuous in SEM observation that physical separation may not be possible. This will affect not only XRD and chemical determinations of even the most carefully separated cavity-filling clay but will influence oxygen isotope and other data as well. The mineralogic and chemical continuum indicates that initially, an oxidizing fluid entered the basalt and then evolved in a closed system. The evolution of the fluid was marked by (1) decreasing oxygen, $\mathrm{K}$, and total $\mathrm{Fe}$ levels and (2) increasing $\mathrm{Mg}, \mathrm{Ca}$, and $\mathrm{Al}$ levels. In addition, a second stage of initially oxidative alteration in lithologic Unit 5 and Subunit $6 \mathrm{~A}$ is indicated by the occurrence of iddingsite, an oxidized alteration product of saponite consisting of an intimate mixture of saponite and goethite. Potassium feldspar is associated with the oxidized zones in this core, and therefore, is most likely a product of the second stage of alteration.

\section{SUMMARY OF THE SEQUENCE OF BASALT ALTERATION IN DSDP HOLE 418A}

1. An initial stage of oxidation with precipitation of $\mathrm{Fe}$ oxide-hydroxides, which was highly variable over space.

2. Precipitation of K-rich clays from the least-evolved fluid: in some places this began with celadonite, in others with a mixed-layer celadonite/nontronite, and in still others with a potassic nontronite.

3. Evolution of the pore fluid from an oxidizing, $\mathrm{K}-$ and $\mathrm{Fe}^{3}$ rich fluid to a reducing, $\mathrm{K}$-poor, $\mathrm{Mg}$-, $\mathrm{Fe}^{2}-, \mathrm{Al}-$, and $\mathrm{Ca}$-rich fluid, the end products of which were saponite and pyrite.

4. Increased $\mathrm{CO}_{2}$ levels result in calcite precipitation.

5. In areas of high permeability, a second, oxidizing fluid circulated through the basalt and altered (a) saponite to iddingsite, releasing silica, and possibly $\mathrm{Ca}$ and $\mathrm{Mg}$, and (b) plagioclase to potassium feldspar, releasing $\mathrm{Ca}$. The products of the second phase of alteration were Fe oxides-hydroxides, iddingsite, potassium feldspar, quartz and/or chalcedony, and calcite. Zeolites formed in either stage and their occurrence, because of its limited extent, was probably controlled by local conditions.

\section{ACKNOWLEDGMENTS}

This study was funded by a grant from Joint Oceanographic Inst., Inc./NSF. Assistance on the SEM by David K. Watkins is gratefully acknowledged; Teresa A. Dunn assisted in operation of the XRD and numerous other tasks; Michael J. Moran assisted with the plates; spectral analyses were performed at the Union Pacific Materials Analysis Lab, Omaha, Nebraska, and at Princeton Gamma-Tech, Inc., Dallas, Texas. Jim Butler of Lamont-Doherty Geological Observatory and Gail Clement of ODP assisted with sampling of the core. Matthew Salisbury, Jim Scott, Joris Gieskes, and Debra Stakes reviewed the manuscript. Their many helpful suggestions are gratefully acknowledged.

\section{REFERENCES}

Anderson, W. L., and Stucki, J. W., 1979. Effect of structural Fe ${ }^{+2}$ on visible spectra of nontronite suspensions. Proc. Int. Clay Conf., 1978; Dev. Sedimentol., 27:76-83.
Baker, I., and Haggerty, S., 1967. Alteration of olivine in basaltic and associated lavas. II. Intermediate and low temperature alteration. Contrib. Mineral. Petrol., 16:258-273.

Bischoff, J. L., 1972. A ferroan nontronite from the Red Sea geothermal system. Clays Clay Miner., 20:217-233.

Bollinger, C., and Semet, M., 1980. Chemical zonation of plagioclase phenocrysts from Leg 51, 52, and 53 basalts. In Donnelly, T., Francheteau, J., Bryan, W., Robinson, P., Flower, M., Salisbury, M., et al., Init. Repts. DSDP, 51, 52, 53, Pt. 2: Washington (U.S. Govt. Printing Office), 1055-1061.

Byerly, G. R., and Sinton, J. M., 1980. Compositional trends in natural basaltic glasses from Deep Sea Drilling Project Holes 417D and 418A. In Donnelly, T., Francheteau, J., Bryan, W., Robinson, P., Flower, M., Salisbury, M., et al., Init. Repts. DSDP, 51, 52, 53, Pt. 2: Washington (U.S. Govt. Printing Office), 957-971.

Clocchiatti, R., 1980. Glassy inclusions in plagioclase and pyroxene phenocrysts in the chilled margin of a pillow lava from Hole 417D, Deep Sea Drilling Project. In Donnelly, T., Francheteau, J., Bryan, W., Robinson, P., Flower, M., Salisbury, M., et al., Init. Repts. DSDP, 51, 52, 53, Pt. 2: Washington (U.S. Govt. Printing Office), 1063-1067.

Decarreau, A., Colin, F., Herbillon, A., Manceau, A., Nahon, D., Paquet, H., Trauth-Baudad, D., and Trescases, J. J., 1987. Domain segregation in Ni-Fe-Mg-smectites. Clays Clay Miner., 35:1-10.

Donnelly, T., Francheteau, J., Bryan, W., Robinson, P., Flower, M., Salisbury, M., et al., 1980. Init. Repts. DSDP, 51, 52, 53: Washington (U.S. Govt. Printing Office).

Donnelly, T. W., Thompson, G., and Salisbury, M. H., 1980. The chemistry of altered basalts at Site 417, Deep Sea Drilling Project Leg 51. In Donnelly, T., Francheteau, J., Bryan, W., Robinson, P., Flower, M., Salisbury, M., et al., Init. Repts. DSDP, 51, 52, 53, Pt. 2: Washington (U.S. Govt. Printing Office), 1319-1330.

Flower, M.F.J., Ohnmacht, W., Robinson, P. T., Marriner, G., and Schmincke, H.-U., 1980. Lithologic and chemical stratigraphy at Deep Sea Drilling Project Sites 417 and 418. In Donnelly, T., Francheteau, J., Bryan, W., Robinson, P., Flower, M., Salisbury, M., et al., Init. Repts. DSDP, 51, 52, 53, Pt. 2: Washington (U.S. Govt. Printing Office), 939-956.

Harder, H., 1978. Synthesis of iron layer silicate minerals under natural conditions. Clays Clay Miner., 26:65-72.

Hart, S. R., 1969. K, Rb, Cs contents and K/Rb, K/Cs ratios of fresh and altered submarine basalts. Earth Planet. Sci. Lett., 6:295-303.

Honnorez, J., Laverne, C., Hubberten, H.-W., Emmermann, R., and Muehlenbachs, K., 1983. Alteration processes in Layer 2 basalts from Deep Sea Drilling Project Hole 504B, Costa Rica Rift. In Cann, J. R., Langseth, M. G., Honnorez, J., Von Herzen, R. P., White, S. M., et al., Init. Repts. DSDP, 69: Washington (U.S. Govt. Printing Office), 509-546.

Humphris, S. E., Thompson, R. N., and Marriner, G. F., 1980. The mineralogy and geochemistry of basalt weathering, Holes 417A and 418A. In Donnelly, T., Francheteau, J., Bryan, W., Robinson, P., Flower, M., Salisbury, M., et al., Init. Repts. DSDP, 51, 52, 53, Pt. 2: Washington (U.S. Govt. Printing Office), 1201-1213.

JCPDS, 1980. Mineral Powder Diffraction File: Swarthmore (Joint Committee on Powder Diffraction Standards).

Juteau, T., Noack, Y., Whitechurch, H., and Courtois, C., 1980. Mineralogy and geochemistry of alteration products in Holes 417A and 417D basement samples (Deep Sea Drilling Project Leg 51). In Donnelly, T., Francheteau, J., Bryan, W., Robinson, P., Flower, M., Salisbury, M., et al., Init. Repts. DSDP, 51, 52, 53, Pt. 2: Washington (U.S. Govt. Printing Office), 1273-1297.

Lawrence, J. R., 1980. Temperatures of formation of calcite veins in the basalts from Deep Sea Drilling Project Holes 417A and 417D. In Donnelly, T., Francheteau, J., Bryan, W., Robinson, P., Flower, M., Salisbury, M., et al., Init. Repts. DSDP, 51, 52, 53, Pt. 2: Washington (U.S. Govt. Printing Office), 1183-1184.

Mering, J., and Oberlin, A., 1971. The smectites. In Gard, J. A. (Ed.), The Electron-Optical Investigation of Clays: Mineral. Soc. Monogr., 3:193-229.

Mevel, C., 1980. Mineralogy and chemistry of secondary phases in low temperature altered basalts from Deep Sea Drilling Project Legs 51, 52, and 53. In Donnelly, T., Francheteau, J., Bryan, W., Robinson, P., Flower, M., Salisbury, M., et al., Init. Repts, DSDP, 51, 52, 53, Pt. 2: Washington (U.S. Govt. Printing Office), 1299-1312. 
Muehlenbachs, K., 1980. The alteration and aging of the basaltic layer of sea floor: oxygen isotope evidence from DSDP/IPOD Legs 51, 52, and 53. In Donnelly, T., Francheteau, J., Bryan, W., Robinson, P., Flower, M., Salisbury, M., et al., Init. Repts. DSDP, 51, 52, 53, Pt. 2: Washington (U.S. Govt. Printing Office), 1159-1167.

Pertsev, N. N., and Rusinov, V. L., 1980. Mineral assemblages and processes of alterations in basalts at Deep Sea Drilling Project Sites 417 and 418. In Donnelly, T., Francheteau, J., Bryan, W., Robinson, P., Flower, M., Salisbury, M., et al., Init. Repts. DSDP, 51, 52, 53, Pt. 2: Washington (U.S. Govt. Printing Office), 1219-1242.

Pritchard, R. G., 1980. Alterations of basalts from Deep Sea Drilling Project Legs 51, 52, and 53, Holes 417A and 418A. In Donnelly, T., Francheteau, J., Bryan, W., Robinson, P., Flower, M., Salisbury, M., et al., Init. Repts. DSDP, 51, 52, 53, Pt. 2: Washington (U.S. Govt. Printing Office), 1185-1199.

Rusinov, V. L., Laputina, I. P., Muravitskaja, G. N., Zvjagin, B. B., and Gradusov, B. P., 1980. Clay minerals in basalts from Deep Sea Drilling Project Sites 417 and 418. In Donnelly, T., Francheteau, J., Bryan, W., Robinson, P., Flower, M., Salisbury, M., et al., Init. Repts. $D S D P, 51,52,53$, Pt. 2: Washington (U.S. Govt. Printing Office), 1265-1271.

Russell, J. D., and Clark, D. R., 1978. The effect of Fe-for-Si substitution on the $b$-dimension of nontronite. Clay Miner., 13:133-137.

Scarfe, C. M., 1980. Secondary minerals in some basaltic rocks from Deep Sea Drilling Project Legs 52 and 53, Hole 418A. In Donnelly, T., Francheteau, J., Bryan, W., Robinson, P., Flower, M., Salisbury, M., et al., Init. Repts. DSDP, 51, 52, 53, Pt. 2: Washington (U.S. Govt. Printing Office), 1243-1246.

Seidemann, D. E., 1977. Effects of submarine alteration on K-Ar dating of deep-sea igneous rocks. Geol. Soc. Amer. Bull., 88:1660-1666.
Shipboard Scientific Parties, 1980. Site 418. In Donnelly, T., Francheteau, J., Bryan, W., Robinson, P., Flower, M., Salisbury, M., et al., Init. Repts. DSDP , 51, 52, 53, Pt. 1: Washington (U.S. Govt. Printing Office), 418-626.

Staudigel, H., Bryan, W. B., and Thompson, G., 1980a. Chemical variation in glass-whole rock pairs from individual cooling units in Holes 417D and 418A. In Donnelly, T., Francheteau, J., Bryan, W., Robinson, P., Flower, M., Salisbury, M., et al., Init. Repts. DSDP, 51, 52, 53, Pt. 2: Washington (U.S. Govt. Printing Office), 977-986.

Staudigel, H., Frey, F. A., and Hart, S. R., 1980b. Incompatible traceelement geochemistry and ${ }^{87 / 86} \mathrm{Sr}$ in basalts and corresponding glasses and palagonites. In Donnelly, T., Francheteau, J., Bryan, W., Robinson, P., Flower, M., Salisbury, M., et al., Init. Repts. DSDP, 51, 52, 53, Pt. 2: Washington (U.S. Govt. Printing Office), 1137-1144.

Sudo, T., Shimoda, S., Yotsumoto, H., and Aita, S., 1981. Electron Micrographs of Clay Minerals: Dev. Sedimentol., 31.

Suquet, H., Iiyama, J. T., Kodama, H., and Pezerat, H., 1977. Synthesis and swelling properties of saponites with increasing layer charge. Clays Clay Miner., 25:231-242.

Thorez, J., 1976. Practical Identification of Clay Minerals: Dijon (G. Lelotte).

Velde, B., 1985. Clay Minerals, a Physico-Chemical Explanation of their Occurrence: Dev. Sedimentol., 40.

Welton, J. E., 1984. SEM Petrology Atlas: Tulsa (Amer. Assoc. Petrol. Geol.).

Date of initial receipt: 24 April 1987

Date of acceptance: 21 September 1987

Ms 102B-111 


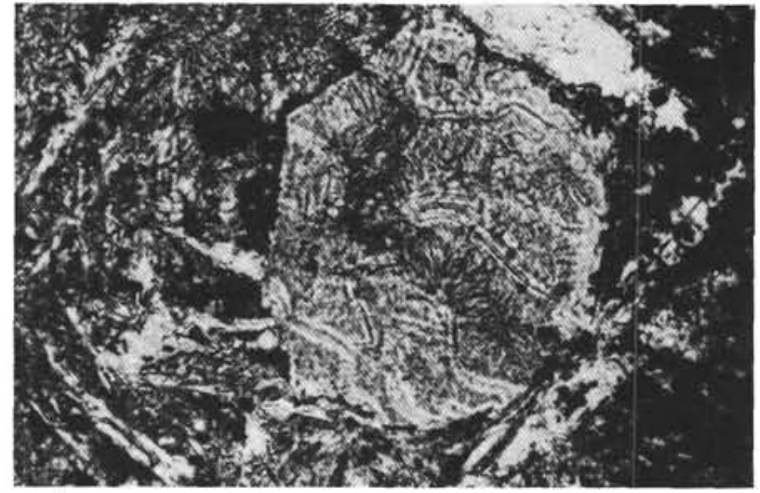

1

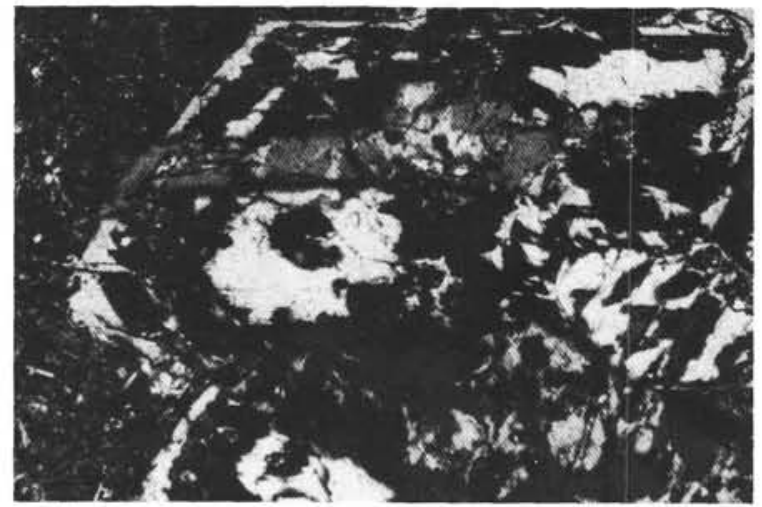

3

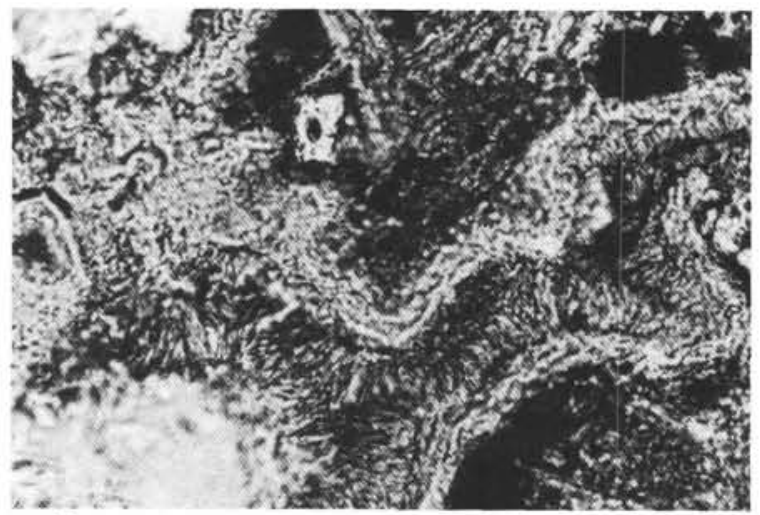

5

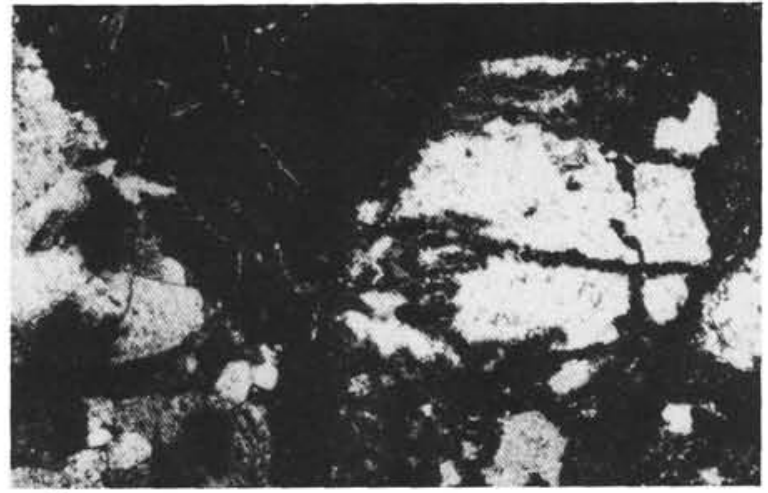

2

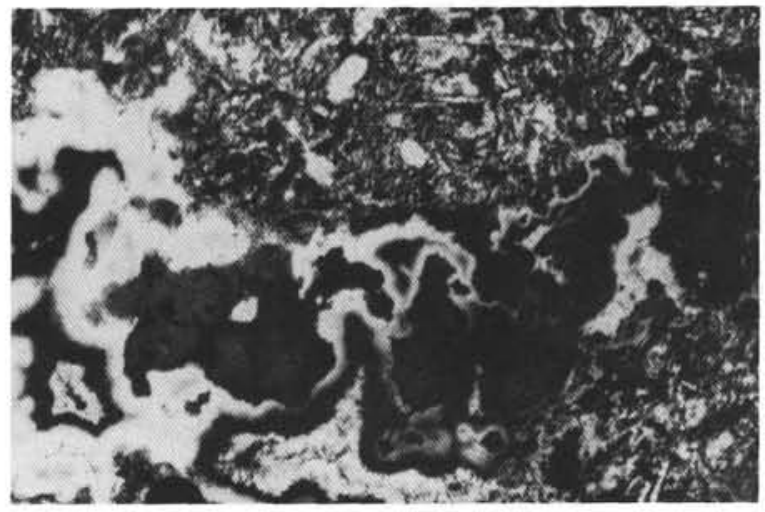

4

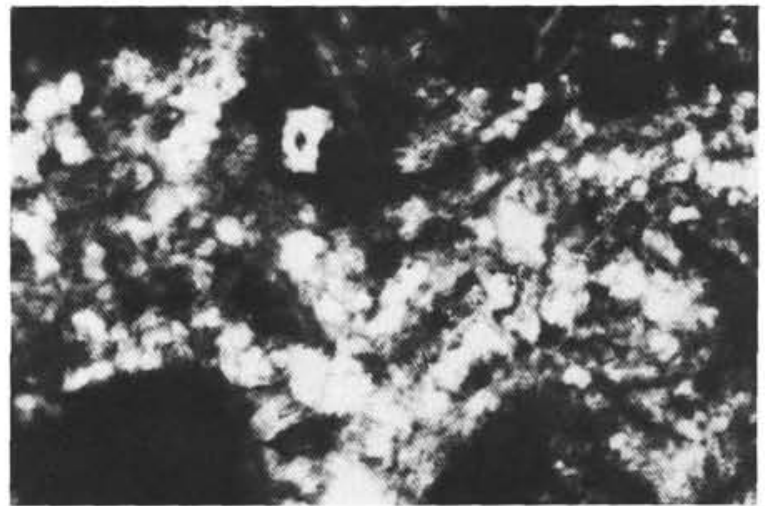

6

Plate 1. Thin-section photomicrographs of alteration products in DSDP Hole 418A basalts. 1. Sample 418A-34-5, 55-60 cm. Olivine phenocryst altered to fine-grained green clay along right outer rim and to fibrous green to brown clay in center. 2. Sample 418A-37-1, 43-47 cm. Plagioclase phenocryst (right) altered to calcite; calcite-filled vein (left); crossed polarizers. 3. Sample 418A-34-5, 55-60 cm. Plagioclase phenocryst partly altered to brown clay; crossed polarizers. 4. Sample 418A-34-5, 55-60 cm. Irregular-shaped void; to right, first phase formed is dark brown to black iron oxide-hydroxide; to left, first phase formed is light green clay; this clay also follows iron oxide-hydroxide at right. Light green phase darkens toward center followed by a dark brown phase (solid black in photo), followed by fibrous brown phase at bottom center. 5. Sample 418A-34-5, 55-60 cm. Irregular-shaped void; part of outside rim formed of dark iron oxide-hydroxide (at right). The next phase is light green, very fine-grained clay followed by dark green to brown fibrous clay. 6. Same view as Figure 5, crossed polarizers. Fibrous clay is highly birefringent. 

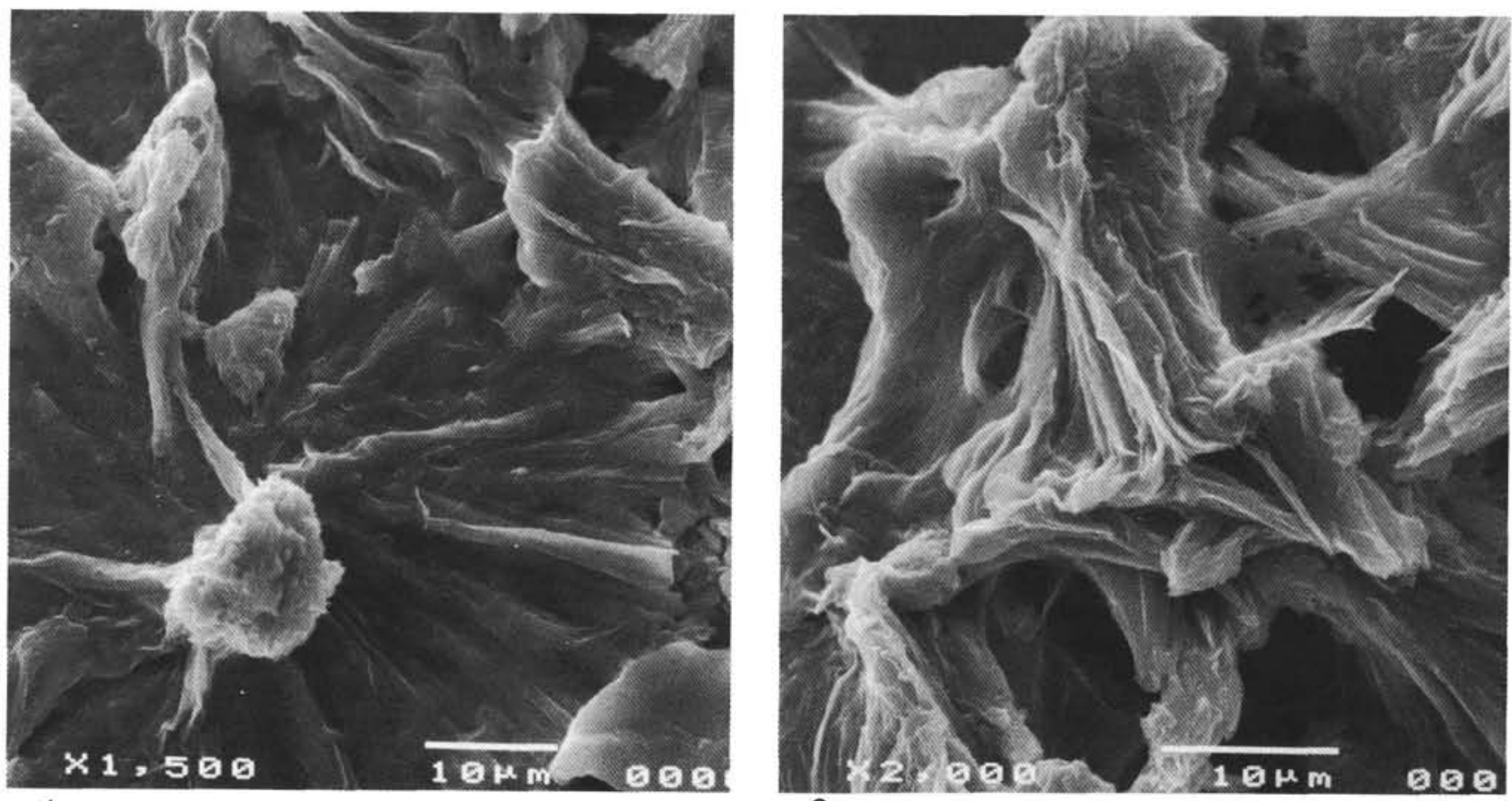

1
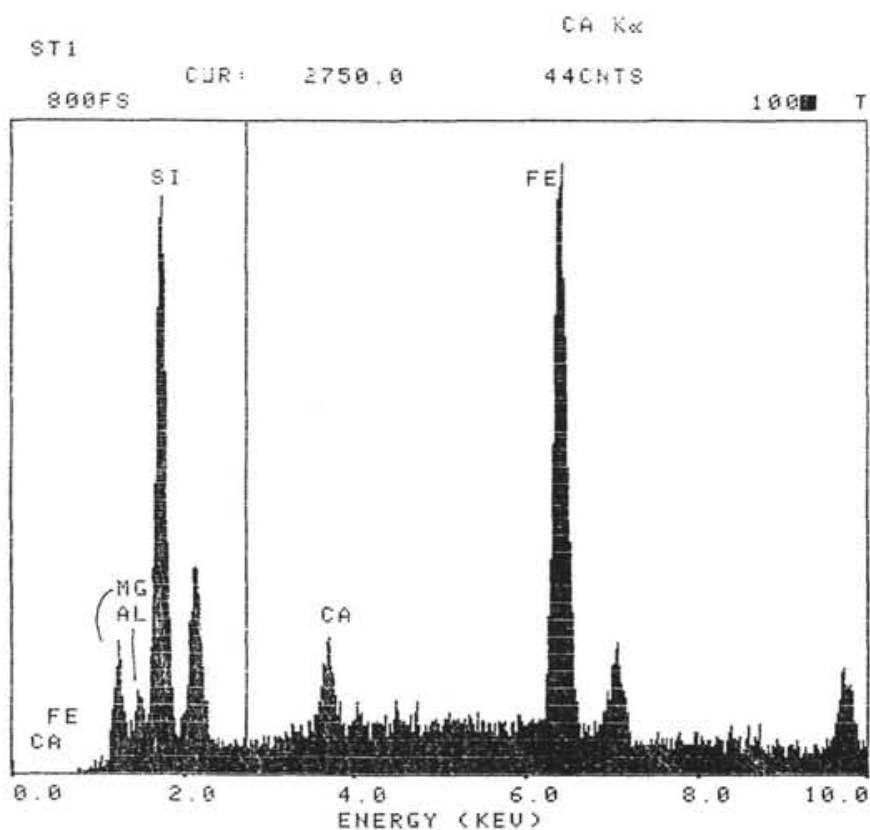

3

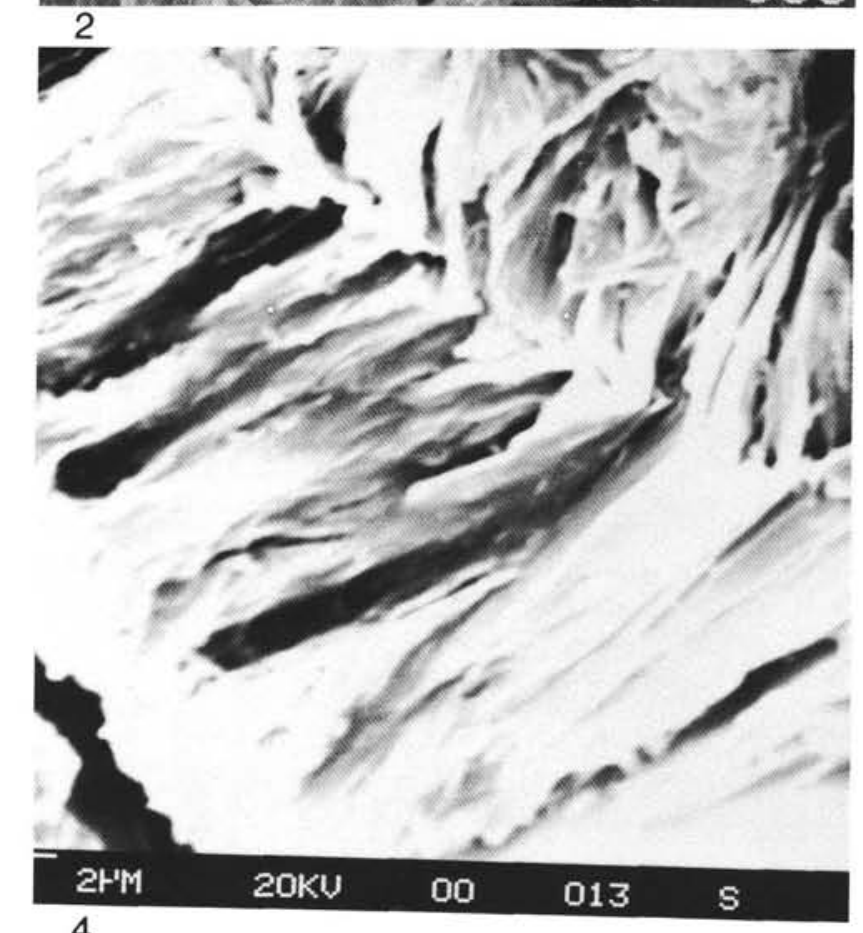

Plate 2. Laths of fibrous clay in DSDP Hole $418 \mathrm{~A}$ basalts. 1. Sample $418 \mathrm{~A}-34-3,51-53 \mathrm{~cm}$. SEM photomicrograph of X-ray diffraction mount. Laths correspond to radiating fibers seen in thin section (PI. 1, Fig. 3) and are saponite. "Hub" of laths may be iddingsite. 2. Sample 418A-34-3, $51-53 \mathrm{~cm}$. SEM photomicrograph of X-ray diffraction mount. At top center and top left, laths of saponite grade into fine-grained, platy clay. 3. Sample 418A-45-2, 40-44 cm. Standardless spectral analysis of laths seen in Figure 4. Cursor is placed approximately where K peak should be. 4. Sample 418A-45-2, 40-44 cm. SEM photomicrograph of fracture mount. Low K laths of saponite with similar morphology to those in Figures 1 and 2 . 

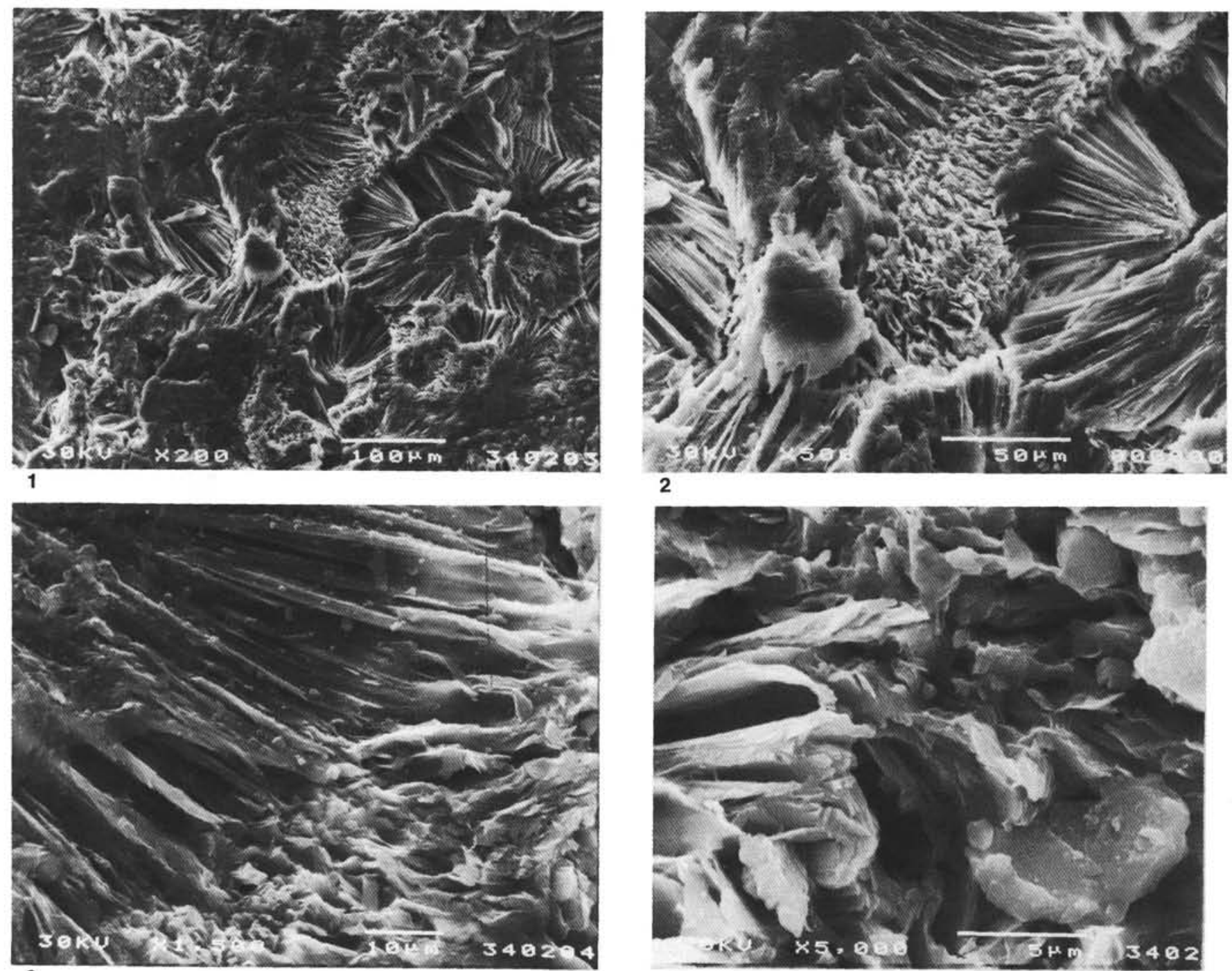

2
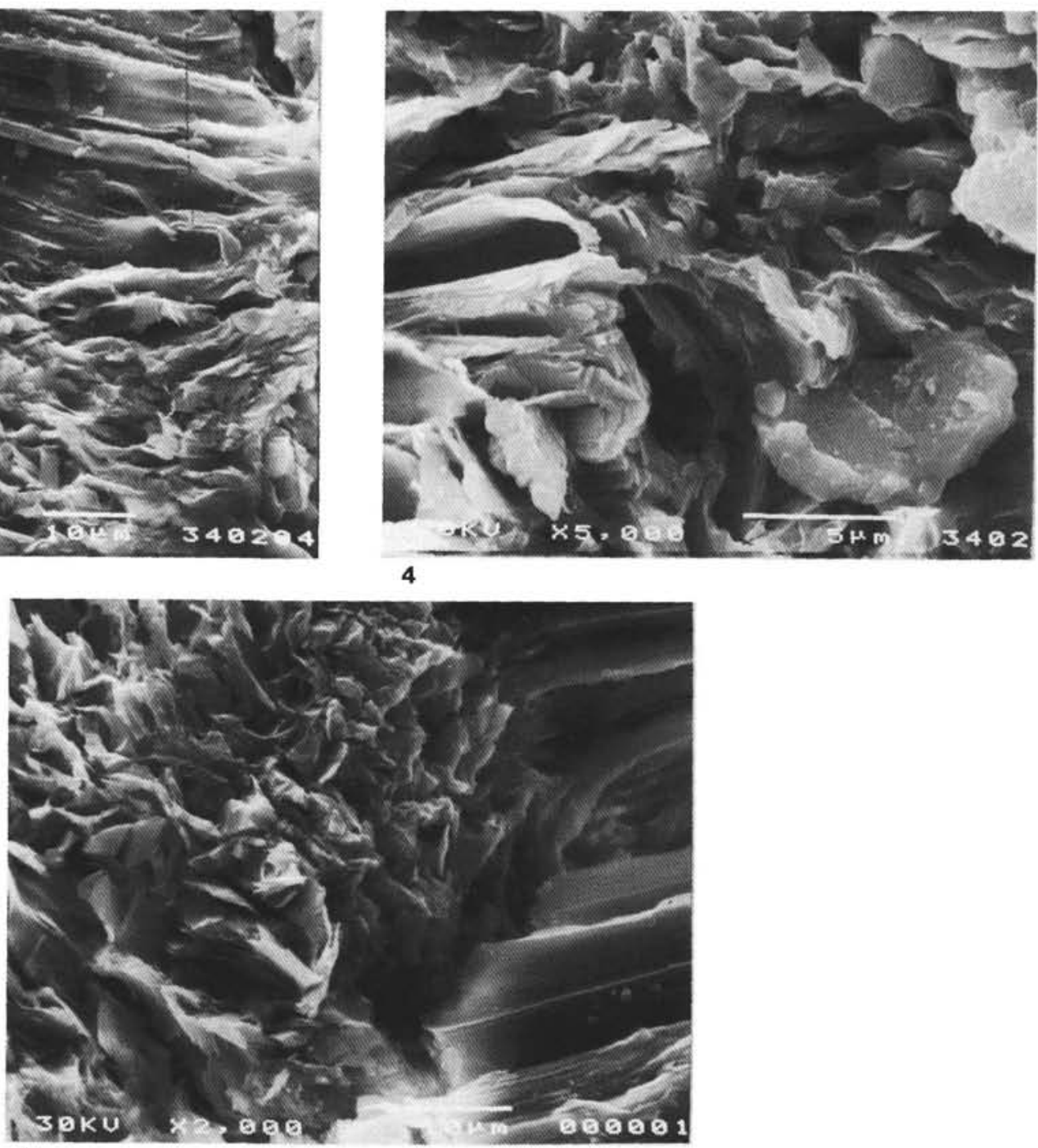

5

Plate 3. SEM photomicrographs of Sample 418A-34-2, 2-4 cm, fracture mount. 1. Radiating masses of laths of saponite fill a large fracture, with alteration of laths to platy iddingsite at center of micrograph. 2. Higher magnification of Figure 1 showing smooth transition of laths to very finegrained material upper left. 3. Top of Figure 2 magnified to show smooth transition of laths to finer-grained material at left and alteration of laths to iddingsite at right. 4. Terminations of unaltered laths are blunt or pointed. 5. Higher magnification of lower center of Figure 2 showing discontinuous boundary between saponite laths and iddingsite. 


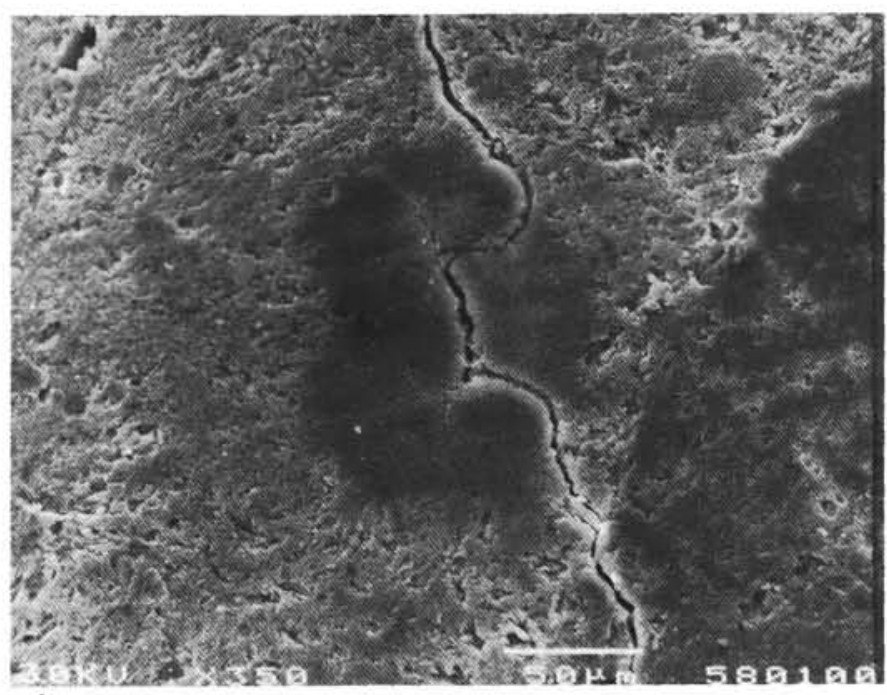

1

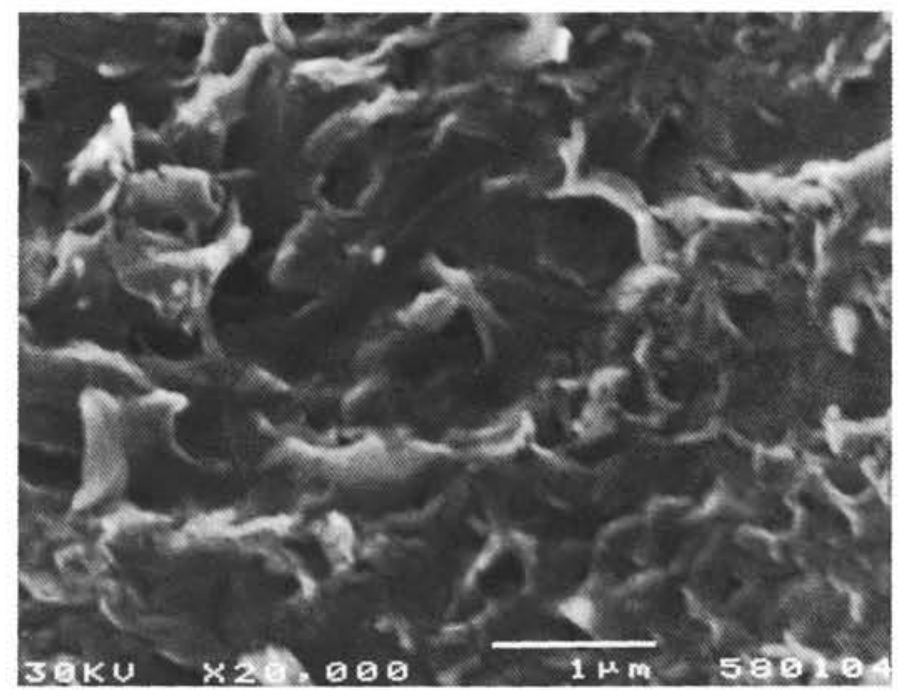

2

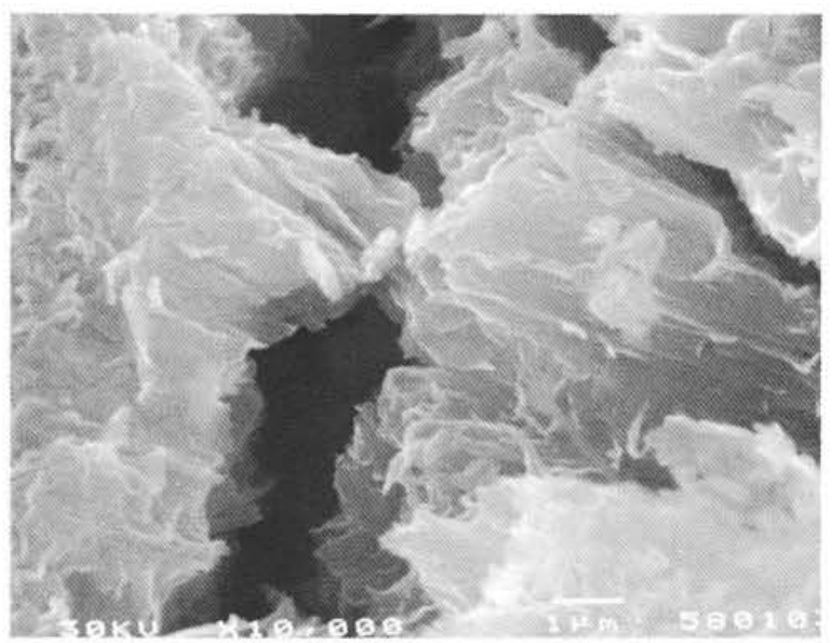

4

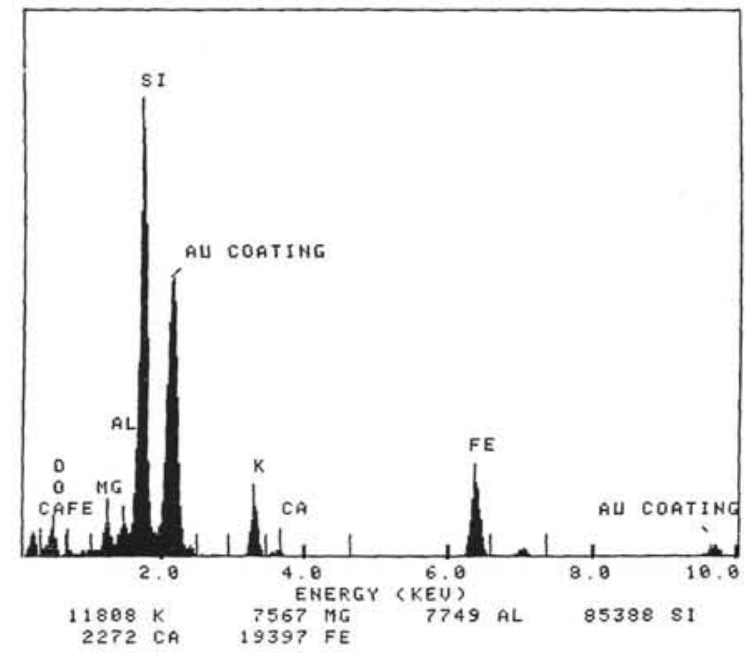

3

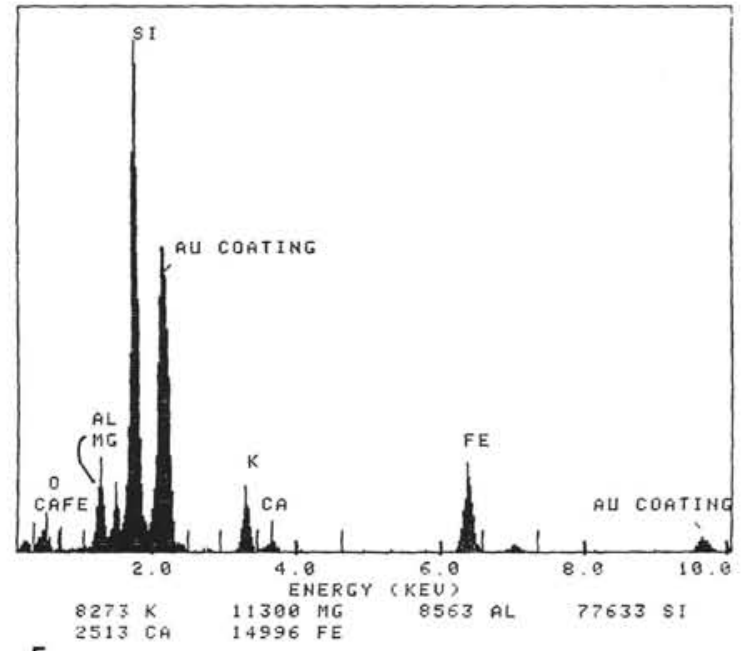

5

Plate 4. SEM photomicrographs and accompanying spectral analyses of Sample 418A-58-1, 41-43 cm, fracture mount. 1. Void (partly resorbed olivine phenocryst?) filled with fine-grained clay. Right part of micrograph shows an unaltered plagioclase phenocryst. 2. Higher magnification of outer rim of filled void from Figure 1 shows extremely fine-grained plates of clay (4. "proto-celadonite," mixed-layer celadonite-nontronite, or potassic nontronite). Higher magnification of core of filled void from Figure 1 showing coarser-grained clay plates. Short laths have formed at left of crack with longer laths formed at right. 3. Standardless spectral analysis of center of Figure 2. $\left(\mathrm{K}_{0.485} \mathrm{Ca}_{0.065}\right)\left(\mathrm{Fe}^{*}{ }_{1.585} \mathrm{Mg}_{0.735} \mathrm{Al}_{0.295}\right)\left(\mathrm{Si}_{3.86} \mathrm{Al}_{0.435}\right) \mathrm{O}_{10}(\mathrm{OH})_{2}$. 5. Standardless spectral analysis from top left of Figure 4. $\left(\mathrm{K}_{0.365} \mathrm{Ca}_{0.09}\right)\left(\mathrm{Fe}^{*}{ }_{1.30} \mathrm{Mg}_{1.13} \mathrm{Al}_{0.28}\right)\left(\mathrm{Si}_{3.765} \mathrm{Al}_{0.235}\right) \mathrm{O}_{10}(\mathrm{OH})_{2}$. 

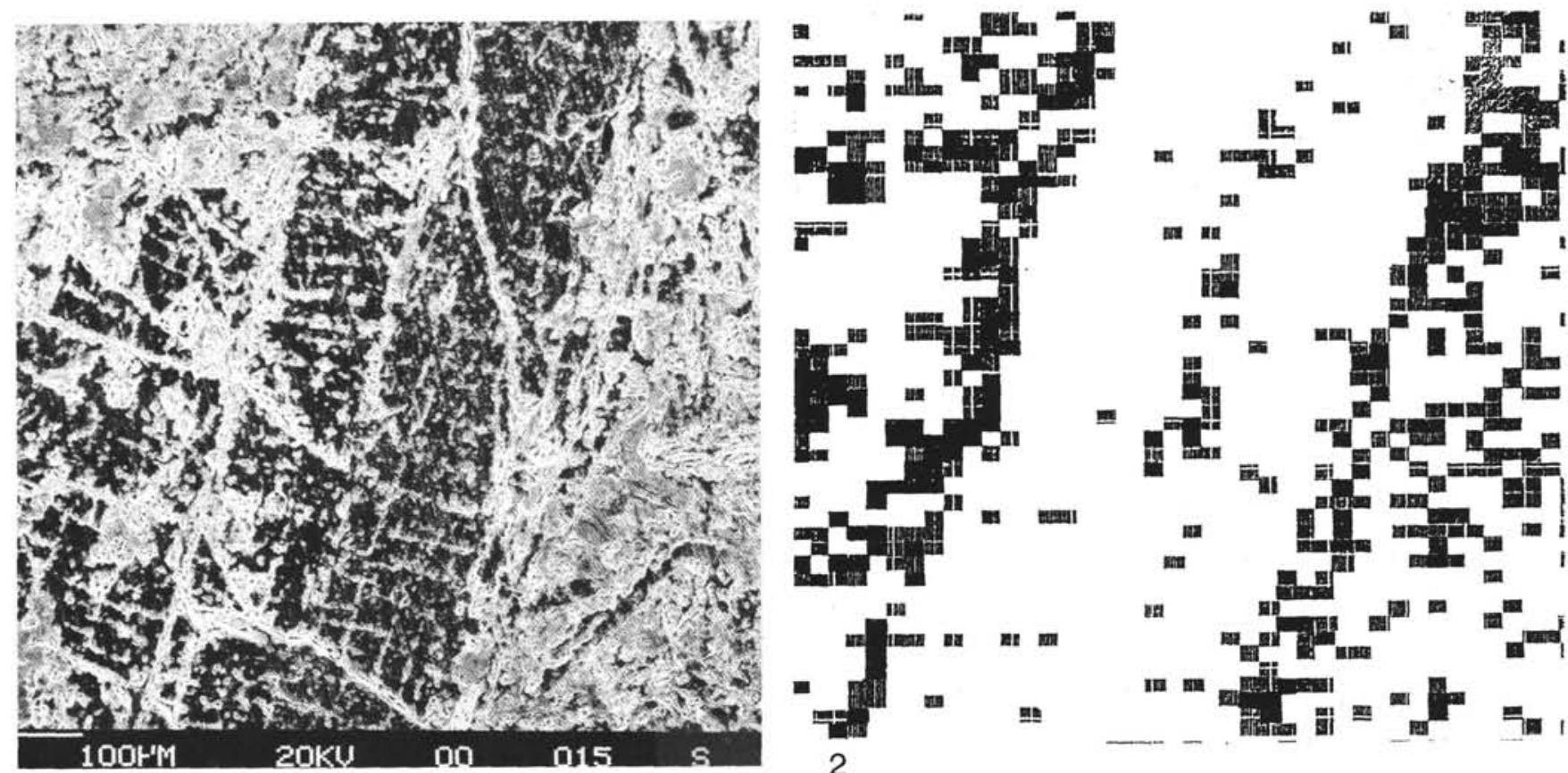

1

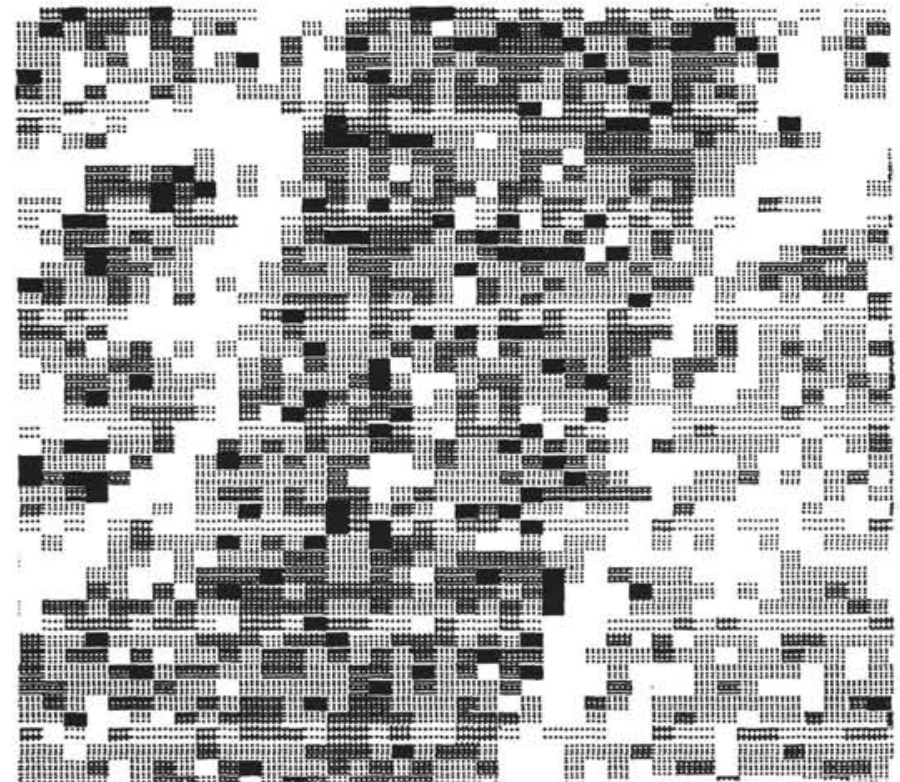

3

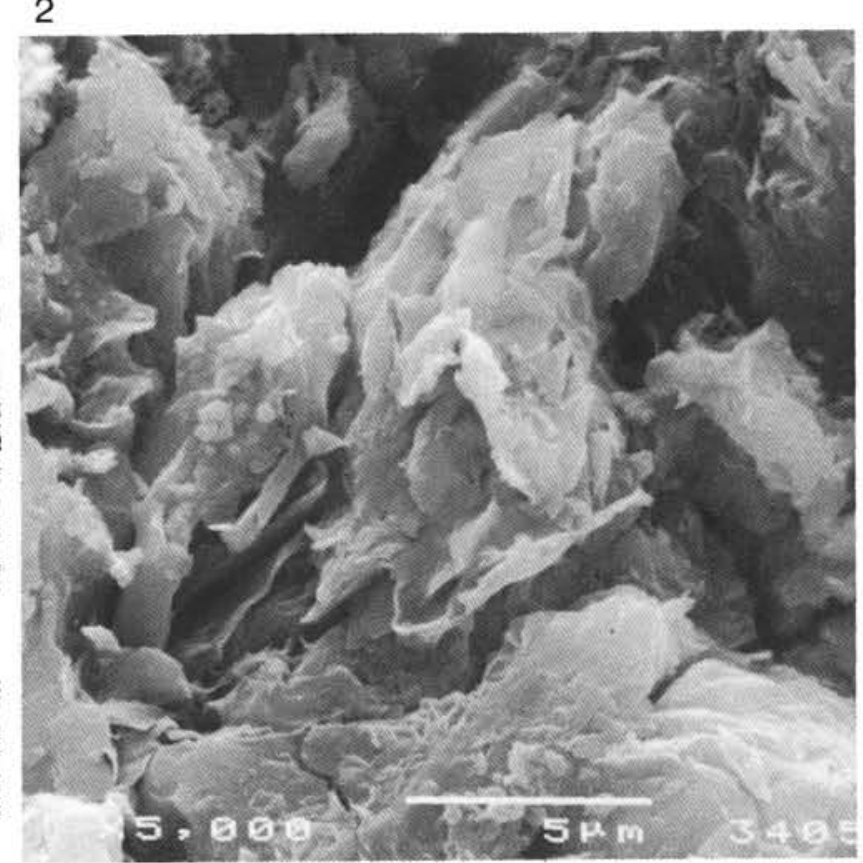

4

Plate 5. Altered plagioclase phenocrysts from DSDP Hole 418A basalts. 1. SEM photomicrograph of Sample 418A-39-1, 72-76 cm, fracture mount. Highly altered plagioclase phenocryst. 2. Spectral map of $\mathrm{K}$ distribution in plagioclase phenocryst of Figure 1 . High $\mathrm{K}$ levels occur along cracks and subvertical cleavage planes. 3. Spectral map of $\mathrm{Ca}$ distribution in plagioclase phenocryst of Figure 1 . Ca has been removed where $\mathrm{K}$ levels are high. 4. SEM photomicrograph of Sample 418A-34-5, 55-60 cm, thin section. Part of acicular (groundmass) plagioclase, with cleavage planes oriented NE to SW, altered to brown clay. Flakes are somewhat thinner than those of green clay (Pl. 4, Fig. 2) and do not grow into laths (Pl. 4, Fig. 4) or radiating fibers (Pl. 1, Fig. 5). 